\title{
E-Tongues/Noses Based on Conducting Polymers and Composite Materials: Expanding the Possibilities in Complex Analytical Sensing
}

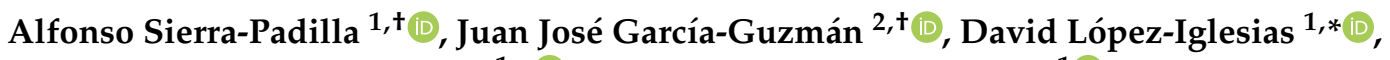 \\ José María Palacios-Santander ${ }^{1, *(1)}$ and Laura Cubillana-Aguilera ${ }^{1}$ (1) \\ 1 Institute of Research on Electron Microscopy and Materials (IMEYMAT), Department of Analytical Chemistry, \\ Faculty of Sciences, Campus de Excelencia Internacional del Mar (CEIMAR), University of Cadiz, Campus \\ Universitario de Puerto Real, Polígono del Río San Pedro S/N, 11510 Puerto Real, Cadiz, Spain; \\ alfonso.sierra@uca.es (A.S.-P.); laura.cubillana@uca.es (L.C.-A.) \\ 2 Instituto de Investigación e Innovación Biomédica de Cadiz (INiBICA), Hospital Universitario ‘Puerta del \\ Mar', Universidad de Cadiz, 11009 Cadiz, Cadiz, Spain; juan.garcia@inibica.es \\ * Correspondence: david.lopeziglesias@uca.es (D.L.-I.); josem.palacios@uca.es (J.M.P.-S.) \\ + These authors equally contributed to the work.
}

check for updates

Citation: Sierra-Padilla, A.; García-Guzmán, J.J.; López-Iglesias, D.; Palacios-Santander, J.M.; Cubillana-Aguilera, L.

E-Tongues/Noses Based on Conducting Polymers and Composite Materials: Expanding the Possibilities in Complex Analytical Sensing. Sensors 2021, 21, 4976. https:// doi.org/10.3390/s21154976

Academic Editor: Oh Seok Kwon

Received: 22 June 2021

Accepted: 18 July 2021

Published: 22 July 2021

Publisher's Note: MDPI stays neutral with regard to jurisdictional claims in published maps and institutional affiliations.

Copyright: (c) 2021 by the authors. Licensee MDPI, Basel, Switzerland. This article is an open access article distributed under the terms and conditions of the Creative Commons Attribution (CC BY) license (https:// creativecommons.org/licenses/by/ $4.0 /)$.

\begin{abstract}
Conducting polymers (CPs) are extensively studied due to their high versatility and electrical properties, as well as their high environmental stability. Based on the above, their applications as electronic devices are promoted and constitute an interesting matter of research. This review summarizes their application in common electronic devices and their implementation in electronic tongues and noses systems (E-tongues and E-noses, respectively). The monitoring of diverse factors with these devices by multivariate calibration methods for different applications is also included. Lastly, a critical discussion about the enclosed analytical potential of several conducting polymer-based devices in electronic systems reported in literature will be offered.
\end{abstract}

Keywords: conducting polymers; electronic tongues; electronic noses; chemometric; discrimination; analysis

\section{Introduction}

In the last decades, intrinsic conducting polymers (CPs) have attracted wide attention due to their excellent electrochemical characteristics, such as tailored electrical conductivity by electronic doping, high environmental stability, and biocompatibility. Their electrical and optical properties establish them as excellent candidates for chemical sensing applications targeting the detection/determination of diverse analytes of interest. In this sense, electrochemical sensors [1-3], gas sensing devices [4], and optical sensors [5,6] have been proposed as providing good analytical features in terms of figures of merit (e.g., sensitivity, limits of detection and quantitation, repeatability, reproducibility, linear range, and robustness). In addition, the modulation of instrumental conditions during the electrodeposition process [7], spin coating [8], or sequential solution polymerization technique [9,10] allows precise control over the thickness and morphology of the resulting conducting coating. This advantage is particularly important in the development of electrochemical and gas sensors [11-13].

In this regard, nanostructures can also be conveniently tailored, leading to analytical sensing improvements [11]. In addition to their morphology, their electrochemical properties can be customized by electronic doping ( $p$ or $n$ ) extensively reported in the bibliography [14,15]. As an illustrative example, the p-doping of PPy is shown in Figure 1. In the first stage, a radical cation is formed by the oxidation of the polymer, inducing a local deformation within the polymer chains, leading to the formation of intermediate 
electronic states between the conducting and valence band. Subsequently, the polymer can be re-oxidized, increasing the number of charge carriers [16].

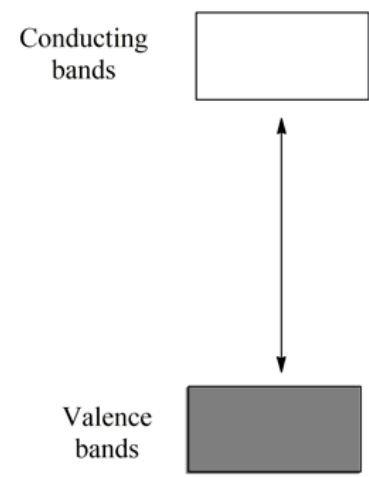

(a)

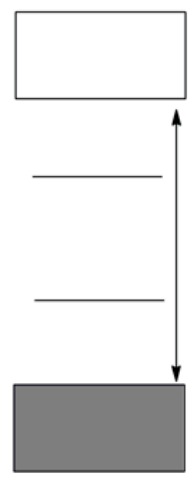

(b)

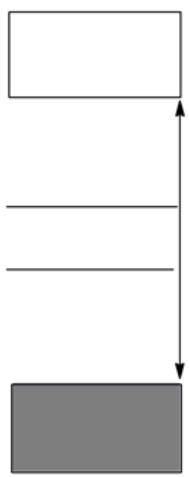

(c)

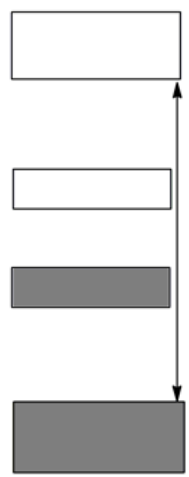

(d)

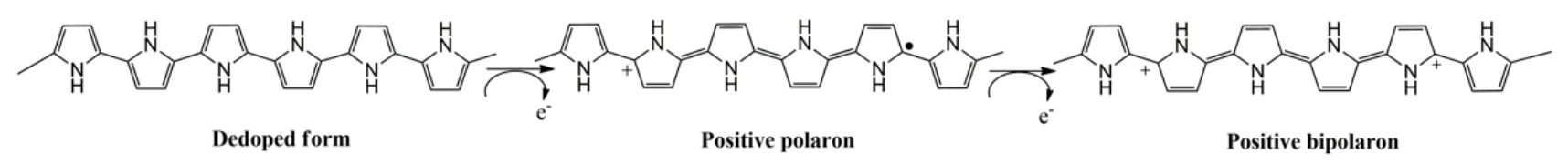

Figure 1. Schematic representation of p-doping process of PPy and structure of electronic bands in different electronic states: (a) de-doped, (b) polaron, (c) bipolaron, (d) bipolaron coupling.

This is the reason why the electrochemical characteristics of the conducting polymers, such as electrical conductivity, can be modulated by electronic doping. This characteristic feature allows the employment of conducting polymers in several applications previously mentioned, such as electrochemical transducers in sensor devices, electrochromism, solar cells, batteries and supercapacitors, among others, proving their versatility in comparison with other electrode materials. Furthermore, the entrapment of enzymes within the polymeric layer may increase the selectivity of the overall system. In this sense, several examples, including horseradish peroxidase [17], tyrosinase [18], and glucose oxidase [19] can be found in the literature.

Despite the high number of intrinsic conducting polymers present in the bibliography, great attention was focused on polythiophene and the corresponding derivatives, as well as on polyaniline and polypyrrole (Figure 2).

\subsection{Polythiophene and Derivatives}

Polythiophene (PTh) have several electroactive properties, such as the remarkable ability for doping/de-doping and high electrical conductivity, which makes them excellent choices for electrochromic supercapacitors and electrochemical applications [20]. Nonetheless, high potentials are required to oxidize the unsubstituted thiophene ring, which can induce the overoxidation of the resulting polymeric film. The inclusion of functional groups in the thiophene monomer leads to a significant reduction of the potentials required for the oxidation due to the presence of electron donor inductive effects [21,22]. Among all the polythiophene derivatives, poly-(3,4-ethylenedioxythiophene) (PEDOT) raised based on its low oxidation potential, which provides a wide oxidation potential window. Hence, the direct electrochemical sensing of different electroactive species can be performed using PEDOT-based electrochemical devices [23,24]. Moreover, the entrapment of biological species onto PEDOT films by several procedures, such as sinusoidal current [25], sinusoidal voltages [26], and drop casting [27] has been achieved. 
<smiles>CC(C)(C)c1ccc(C(C)(C)C)s1</smiles>

Polythiophene (PTh)<smiles>Cc1sc(C(C)(C)C)c2c1OCCO2</smiles>

\section{Poly-(3,4-ethylenedioxythiophene) (PEDOT)}<smiles>CC(C)(C)c1ccc(C(C)(C)C)[nH]1</smiles>

Polypyrrole (PPy)

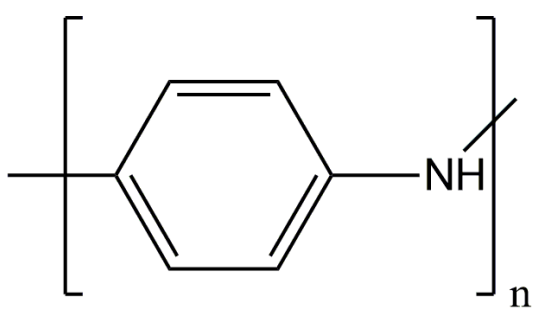

Polyaniline (PANI)

Figure 2. Chemical structure of the most relevant intrinsic conducting polymers.

\subsection{Polyaniline}

Polyaniline (PANI) is constituted by three ideal oxidation states: leucoemeraldine (reduced form), emeraldine (half-oxidized state), and pernigraniline (fully oxidized state) [28]. The reversible redox conversion between emeraldine base, non-conducting form, to emeraldine salt, conducting form, has been exploited in several electronic devices, e.g., gas sensors, supercapacitors, electrochromic devices, and electrochemical sensors [29-32]. Regarding electrochemical devices, the electroactivity of polyaniline film plays a relevant role. Low electroactivity of the polyaniline film at neutral and basic electrolytic media can be found, which can be ascribed to the deprotonation of emeraldine salt at higher $\mathrm{pH}$. Polyaniline composites were developed and used for electrochemical sensing to avoid the deprotonation of the conducting polymer backbone. In this sense, self-doped polyaniline-based devices showed electroactivity at neutral media [33-35].

\subsection{Polypyrrole}

Polypyrrole (PPy) is a versatile conducting polymer, characterized by redox properties, high electrical conductivity, and reversible redox switching [36]. The redox conversion of neutral form (yellow) to oxidized form (black grey) is useful for electrochromic applications [37]. The electrochemical performance of polypyrrole composites towards several compounds for electrochemical and gas sensors is also reported in several review papers [38-40]. Furthermore, the entrapment of several enzymes in conducting polypyrrole films to design biosensor devices is also reported in the bibliography [41-43].

Based on the previous subsections, the feasible employment of these conducting polymers in complex and high demanding sensing devices, such as electronic tongues (E-tongues) and noses (E-noses), is evident.

\subsection{Electronic Systems: Electronic Tongues and Noses}

Electronic systems (E-tongues/noses) emerged during the beginning of the 21st Century as useful low-time consuming tools to obtain qualitative and quantitative information about several biological, pharmaceutical, and food samples. Currently, the demand for these devices has been largely increasing in the last years. The terms electronic "tongue" or 
"nose" arose due to their mimicking properties of taste and smell senses, respectively. To illustrate their growing scientific interest, the number of reports related to their development published per year is shown in Figure 3.

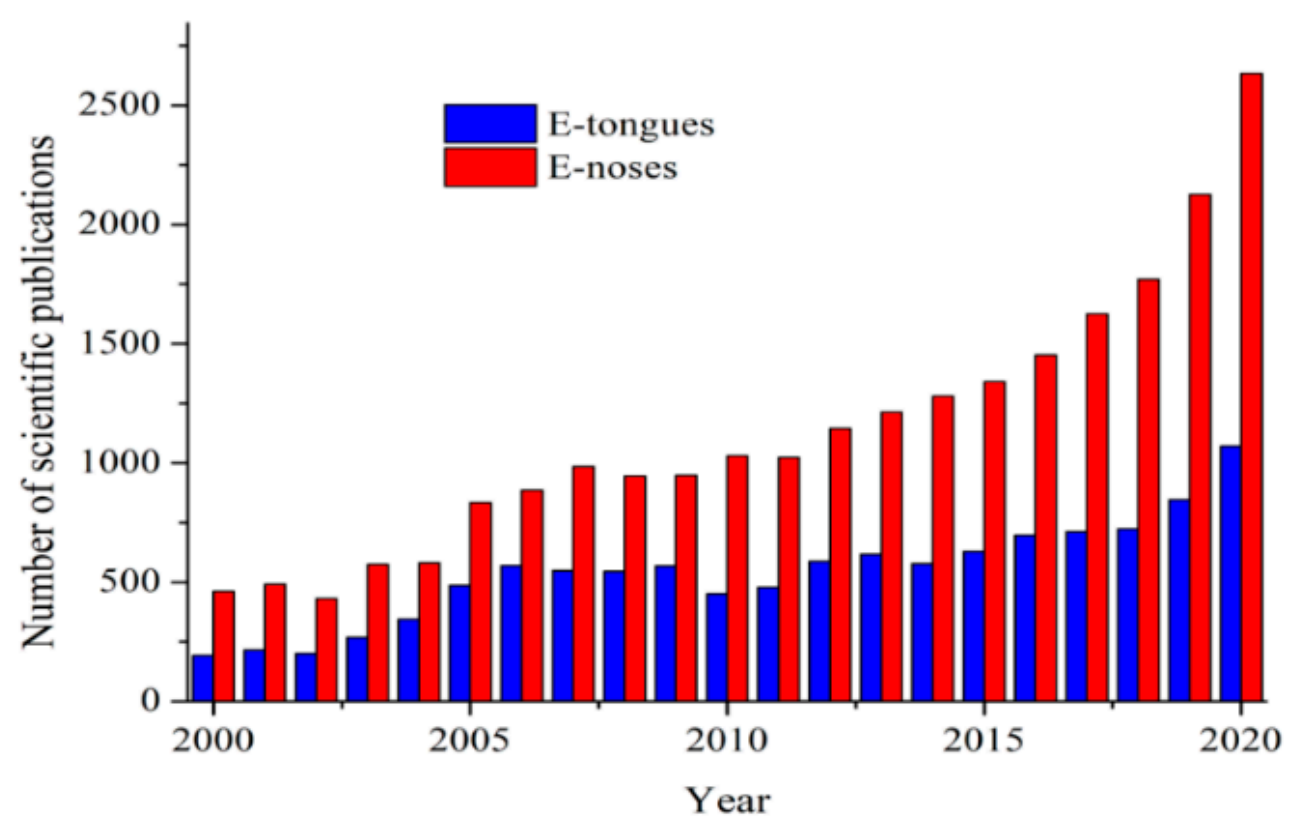

Figure 3. Number of scientific publications containing "electronic tongues" (E-tongues) and "electronic noses" (E-noses) terms published per year. Information obtained from Science Direct database (2021).

E-tongues/noses are mainly constituted by two blocks: a sensing unit, able to produce signals from target chemical species, and their processing part usually based on multivariate calibration methods. The latter permits the discrimination of samples, control of chemical adulteration (qualitative analysis), and correlation between experimental results and chemical parameters (quantitative analysis) by monitoring several features of the target samples [44-48].

\subsubsection{Sensing Unit: Electrochemical Sensor Arrays}

Generally, several sensors are deployed as sensor arrays (sensing unit) in E-tongues and E-noses. The use of CPs coatings in the preparation of these sensors is strongly recommended due to their tailored electrochemical properties, reached by electronic doping, as well as their nanostructured morphology and thickness-controlled surface, as it was previously mentioned at the beginning of this section.

\subsubsection{Processing of the Collected Data: Multivariate Methods}

Responses collected from unspecific sensor matrices are classified in specific response patterns and subsequently processed by chemometric analysis. The main multivariate techniques employed in the data analysis are principal component analysis (PCA) and partial least squares regression (PLS). PCA tries to reduce the number of highly correlated variables, converting them into uncorrelated variables which contain as much information as possible of the large data set (namely, principal components). By applying this procedure, samples are organized in groups, known as clusters, allowing their distinction according to different features. PLS intends to establish a correlation between independent and dependent variables. Thus, predictive models can be built, obtaining useful information [49]. 


\subsubsection{Novelty of the Work}

Several pieces of research previously revised the application of conducting polymers and different conducting composites with nanomaterials, e.g., carbon nanomaterials, noble metal, and metal oxide nanoparticles, electrochemical sensors, biosensors, gas sensors, and immunosensors, among others [50-54]. In this review, the principal aspects concerning the development of E-tongues and E-noses based on CPs will be addressed. Firstly, the sensing units of both electrochemical sensors and chemiresistors will be explained, highlighting their composition. Secondly, the application of the resulting conducting polymer-based devices in the qualitative and quantitative analysis of the target samples by means of specific chemometric tools will be overviewed as well. Moreover, their performance will be discussed and related to characteristic features, such as surface morphology, thickness, and electrical conductivity. Finally, future trends of E-tongues and E-noses based on CPs and hybrid composite materials will be carefully analyzed and discussed.

\section{Electronic Tongues (E-Tongues) Based on CPs}

\subsection{Sensing Unit: Electrochemical Sensors}

The sensing mechanism of conducting polymer-based electrochemical devices has been deeply studied in different pieces of research $[55,56]$. As an illustrative example, the electrochemical oxidation of ascorbic acid and dopamine using PEDOT-modified sensors in a neutral medium was evaluated. Attractive ionic forces between ascorbate, usually found at neutral medium, and the conducting layer was proposed, leading to an electrocatalytic effect for ascorbic acid oxidation. On the other hand, a repulsive interaction between dopamine and the p-doped conducting film was established [57]. Therefore, the PEDOT sensor allows the simultaneous voltammetric determination of both analytes in neutral medium (Figure 4).

\section{Interaction analyte-surface}

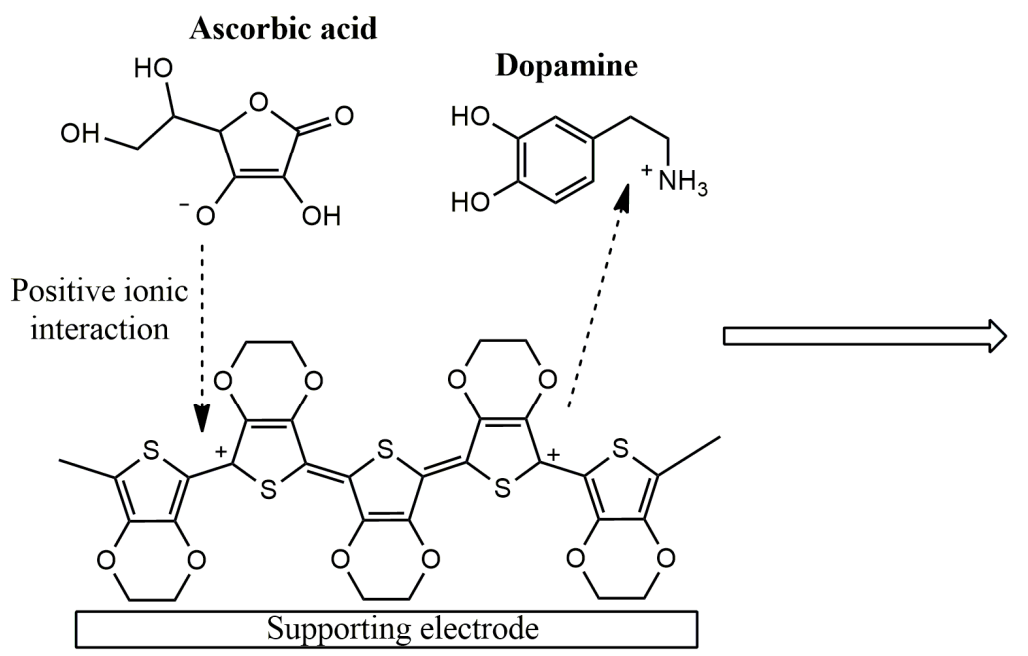

\section{Signal processing (Differential Pulse voltammetry)}

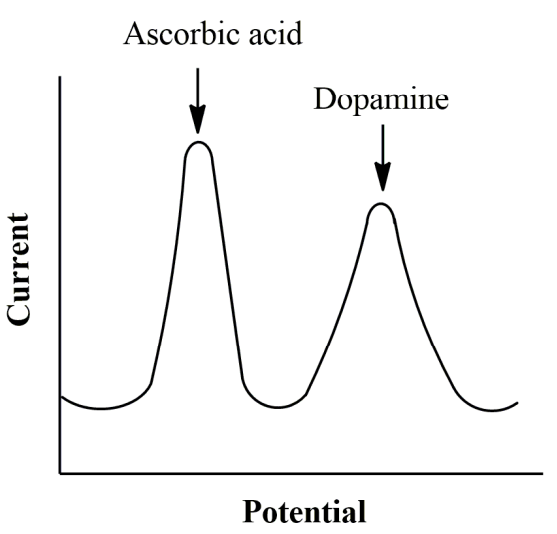

Figure 4. Proposed mechanism for ascorbic acid and dopamine interaction using PEDOT-modified electrodes.

The interaction between the polymeric backbone and the target analyte was also reported for other heterocyclic conducting polymers, such as 3-amino-5-mercapto-1,2,4triazole [58,59], polyaniline [60], and poly-(N-dimethylaniline) [61].

In addition to their doping properties, the inclusion of redox mediators in the conducting film may improve the electrochemical performance of the resulting devices for sensing diverse analytes of interest. In this regard, several electrochemical sensors employed in electrochemical assays in buffer and real matrices are listed in Table 1. 
Table 1. Electrochemical sensors based on polythiophene (PTh), poly-(3,4-ethylenedioxythiophene) (PEDOT), polyaniline (PANI), and polypyrrole (PPy) currently reported in literature.

\begin{tabular}{|c|c|c|c|c|c|c|}
\hline \multirow{2}{*}{ Electrochemical Device } & \multirow{2}{*}{ Analyte } & \multirow{2}{*}{ Working Media } & \multirow{2}{*}{ Sample } & \multicolumn{2}{|c|}{$\begin{array}{l}\text { Analytical } \\
\text { Parameters }\end{array}$} & \multirow{2}{*}{ Ref. } \\
\hline & & & & $\begin{array}{l}\text { LD } \\
(\mu \mathrm{M})\end{array}$ & $\begin{array}{c}\text { LR } \\
(\mu \mathrm{M})\end{array}$ & \\
\hline \multicolumn{7}{|c|}{ PTh } \\
\hline $\mathrm{MWCNT} / \mathrm{PTh} / \mathrm{Pt}$ & BPA & PBS pH 7.5 & Water & 0.009 & $0.05-0.4$ & {$[62]$} \\
\hline $\mathrm{MnO}_{2} / \mathrm{PTh} / \mathrm{rGO} / \mathrm{GCE}$ & MP & PBS pH 7 & Human urine and blood & 0.0057 & $0.5-10$ & [63] \\
\hline GO-4-ATP-Au-PTh/Au GCE & Nicotine & PBS pH 7 & Serum, urine, cigarette & 0.17 & $1.0-30$ & {$[64]$} \\
\hline PTh-AgBr & Glucose & $\mathrm{NaOH}$ & Human blood plasma & 0.31 & $4-5000$ & {$[65]$} \\
\hline PTh-Ag/GCE & L-Tryp & PBS pH 7 & Soybeans extract & 0.020 & $0.2-400$ & [66] \\
\hline \multicolumn{7}{|c|}{ PEDOT } \\
\hline PEDOT/IL/GCE & DA & PBS pH 7.4 & Human urine & 0.033 & $0.2-328$ & [67] \\
\hline $\begin{array}{c}\text { UiO-66- } \\
\mathrm{NH}_{2} @ P E D O T / G A / G C E\end{array}$ & PCMC & ABS pH 6 & Tap water & 0.2 & $0.6-18$ & [68] \\
\hline PEDOT/AG/GCE & $\mathrm{AC}$ & PBS pH 7 & Local tablets & 0.041 & $0.15-5881$ & [69] \\
\hline $\mathrm{Cu}_{2} \mathrm{O} / \mathrm{PEDOT} / \mathrm{MWCNT}$ & Glucose & $\mathrm{NaOH}$ & Human blood serum & 0.04 & $0.495-374$ & [70] \\
\hline GC/PEDOT-AuNPs-SV & CA & PBS pH 7 & Juice & 4.24 & $10-1000$ & [71] \\
\hline PEDOT-Tyr/SNG-C & CA & PBS pH 7 & Wine, beer & 4.33 & $10-300$ & [72] \\
\hline PEDOT/PEDOT-SH/Au & Nitrite & PBS pH 6.9 & Tap water, milk & 0.051 & $0.15-1000$ & [73] \\
\hline $\mathrm{PEDOT} / \mathrm{Au}$ & UA & PBS pH 6.6 & Milk & 7.0 & $6-200$ & [74] \\
\hline GCE/PEDOT-MC/AgNPs & Rutin & PBS pH 3 & Tablets & 0.0035 & $0.005-0.5$ & [75] \\
\hline $\mathrm{Pt} / \mathrm{PEDOT}-\mathrm{PBNPS}$ & $\mathrm{H}_{2} \mathrm{O}_{2}$ & ABS pH 5.5 & Human blood & 1.4 & 5-1000 & [76] \\
\hline \multicolumn{7}{|c|}{ PANI } \\
\hline $\mathrm{Co}_{3} \mathrm{O}_{4} @ \mathrm{PANINFs} / \mathrm{GCE}$ & Glucose & PBS pH 7.4 & Human serum & 60 & $100-8000$ & [77] \\
\hline 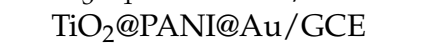 & Hydrazine & $\mathrm{NH}_{3} / \mathrm{NH}_{4}^{+} \mathrm{pH} 9$ & Power plant sewage & 0.15 & $0.9-1200$ & [78] \\
\hline $\mathrm{PANI} / \mathrm{SnO}_{2} / \mathrm{GCE}$ & Nitrite & PBS pH 6 & - & 0.04 & $0.12-7777$ & [79] \\
\hline $\mathrm{GCE} / \mathrm{PANI}-\mathrm{Fe}_{3} \mathrm{O}_{4}$ & $\mathrm{DA}$ & PBS pH 7 & Water & 0.176 & $0.2-2.4$ & [80] \\
\hline GCE/PANI-NiO & $\mathrm{DA}$ & PBS pH 7 & Water & 0.166 & $0.2-2.4$ & {$[80]$} \\
\hline$\alpha-\mathrm{Fe}_{2} \mathrm{O}_{3} / \mathrm{PANI} / \mathrm{GCE}$ & $\mathrm{UA}$ & PBS pH 7 & Human urine & 0.038 & $0.01-5$ & [81] \\
\hline NiO-NPs@PANINS/SPE & Glucose & $\mathrm{NaOH}$ & Human blood serum & 0.06 & $1-3000$ & [82] \\
\hline MeGO/PANI & AA & PBS pH 7.4 & - & 2.0 & $8-5000$ & [83] \\
\hline \multicolumn{7}{|c|}{ PPy } \\
\hline $\mathrm{Fe}_{3} \mathrm{O}_{4} @ P P y / M W C N T s / G E$ & AT & $\mathrm{BR}$ pH 4 & Serum, tablets & 0.0230 & $0.0314-201$ & [84] \\
\hline AuNP/PPy/GCE & L-dopa & PBS pH 7 & Urine & 0.075 & $0.1-6.0$ & [85] \\
\hline PDA/PPy/GCE & UA & $\mathrm{PBS} \mathrm{pH} 8$ & Human serum, urine & 0.11 & $0.5-40$ & [86] \\
\hline PGE/CuO-NPs/PPy & $\mathrm{TR}$ & PBS pH 8.5 & Tablets & 0.001 & $0.005-380$ & [87] \\
\hline PPy:LAC & Lactate & $\mathrm{KNO}_{3}$ & Human tear, rat blood & 81.0 & $100-10,000$ & [88] \\
\hline $\mathrm{AuCu} / \mathrm{PPy} / \mathrm{Cu}-\mathrm{TCCP}$ & $\mathrm{H}_{2} \mathrm{O}_{2}$ & PBS pH 8 & Medical $\mathrm{H}_{2} \mathrm{O}_{2}$ solution & 0.0067 & $0.71-24,100$ & [89] \\
\hline
\end{tabular}

AA: ascorbic acid; ABS: acetic buffer solution; AC: acetaminophen; AT: atorvastatin; ATP: adenosine triphosphate; BPA: bisphenol A; BR: Britton-Robinson; CA: caffeic acid; CuO-NPs: copper oxide nanoparticles; DA: dopamine; PTh: polythiophene; GA: graphene aerogel; GCE: glassy carbon electrode; IL: ionic liquid; LAC: lactate; LD: limit of detection; LR: linear range; L-Tryp: L-tryptophan; MC: mesoporous carbon; MP: methyl parathion; MWCNT: multi-walled carbon nanotubes; PANI: polyaniline; PANINS: polyaniline nanofibers; PBNPS: Prussian blue nanoparticles; PBS: phosphate buffer solution; PCMC: p-chloromethylcresol; PEDOT: poly-(3,4-ethylenedioxythiophene); PGE: pencil graphite electrode; PPy: polypyrrole; rGO: reduced-graphene oxide; SPE: screen-printed electrode; SV: sinusoidal voltage; TCCP: meso-tetra-(4-carboxyphenyl)-substituted porphyrins; TR: tramadol; and UA: uric acid.

As it can be observed in the previous table, conducting polymers are very versatile in the determination of a wide variety of samples, including beverages (milk, wine, beer, juice, and water), pharmaceutical tablets (rutin and dopamine), and human body fluids (urine, blood, tears, and serum). Importantly, their analytical parameters, in terms of limit of detection and linear range, are competitive in comparison with other non-conducting polymer electrochemical sensors reported in literature, such as ceramic carbon and carbon paste modified sensors [90-92]. 
Furthermore, several analytes can be detected and quantified using conducting polymer-based electrochemical devices, all at once by single measurement. For example, PEDOT-modified materials were employed in the electrochemical sensing of ascorbic acid, uric acid, and dopamine simultaneously in biological samples, suggesting an electrocatalytic effect caused by the high ionic affinity between ascorbate anions and the conducting film at neutral media, as previously discussed in this subsection [93]. Other electrochemical sensors used for simultaneous determination purposes recently reported in bibliography can be also stated. In this sense, a PTh derivative was used in the electrochemical assays of three nitrophenol isomers in buffer and water media [94]. The modification of PANI film with a metal ion allowed the analysis of a quaternary mixture containing ascorbic acid, dopamine, uric acid, and tryptophan [95]. PANI-modified sensors can also detect simultaneously catechol, hydroquinone and resorcinol [96], lead and cadmium [97], and dopamine and uric acid [98]. PPy hydrogels and PPy-modified hydrogels are also highlighted for electroanalytical simultaneous sensing, as widely discussed in literature [99,100].

Not only can materials based on electrodeposited conducting polymer layers be employed as sensor transducers, but bulk material composites based on conducting polymers were reported in the bibliography as alternative electrochemical devices as well. For example, a carbon paste and PANI nanocomposite was employed for analytical sensing, suggesting a synergistic effect between starch, PANI, and carbon nanotubes [101,102]. Additionally, ceramic carbon-conducting polymer materials were also developed by means of sol-gel technology assisted by high-energy ultrasound. Resulting devices displayed remarkable analytical performance in the quantification of major phytocannabinoids, ascorbic acid, and 4-chloro-3-methylphenol. Furthermore, their surface can be renewed easily and quickly using either electrochemical or mechanical procedures $[103,104]$. Thus, similar bulk composite devices are promising materials for sensor arrays in electronic tongues, as discussed in the next subsection.

\subsection{Analytical Application of E-Tongues}

Electronic tongues have been successfully applied in the analysis of a wide range of samples. Their multiple applications in different ambits employing potentiometric and/or voltammetric sensor arrays were overviewed by many researchers [105-108].

The preliminary studies regarding electronic tongues containing conducting polymers developed by C. Mattoso and coworkers involves the use of ultrathin layers of PPy electrodeposited and their application in the distinction of some beverages [109-111]. One year later, De Saja developed an E-tongue by using PPy, PTh, and PANI coatings as voltammetric sensor arrays. Each one provided characteristic voltammetric signals, increasing the cross-selectivity of the resulting device and discriminating solutions with different tasting properties [112]. Moreover, conducting polymers were tested as well for qualitative analysis of tea and coffee samples and the quantitative determination of specific analytes contained in green Korean tea [113]. Notably, subsequent sensor arrays composed by conducting electrodeposited polymer coatings are relevant for food analysis at industrial scale. Table 2 shows several electronic tongues employed in electroanalysis of some foodstuffs.

A cursory inspection of Table 2 exposes the high versatility of electronic tongues for beverage analyses, such as wine, beer, and juices. Regarding the analysis of wines and musts, Pigani et al. proposed an interesting application to assess the influence of ripening time. Voltammetric responses displayed with PEDOT and sonogel-carbon electrodes for must samples collected after 10 and 50 days of ripening (namely T0 and T4, respectively), were remarkably different, as is shown in Figure 5. Thus, the use of voltammetric sensors in this work to provide useful information about the ripening process, in addition to other relevant parameters studied by chemometric analysis, such as $\mathrm{pH}$, total acidity, total sugars, and anthocyanins [114]. Furthermore, the shape and scan evolution of voltammetric signals are actually informative with respect to the discrimination of samples analyzed, as is detailed in literature [115]. Likewise, PPy films deposited with different doping agents were also reported as sensor arrays of E-tongue systems applied to red wines. 
Table 2. Electronic tongues containing sensors based on conducting polymer coatings applied in the analysis of food samples.

\begin{tabular}{|c|c|c|c|c|c|}
\hline \multicolumn{2}{|r|}{ Sensor Array } & \multirow{2}{*}{ Sample } & \multirow{2}{*}{ Use } & \multirow{2}{*}{$\begin{array}{l}\text { Multivariate } \\
\text { Calibration }\end{array}$} & \multirow{2}{*}{ Ref. } \\
\hline No CP Sensor & CP Sensor & & & & \\
\hline SNG-C & $\mathrm{PEDOT} / \mathrm{Pt}$ & Musts & $\begin{array}{c}\text { Discrimination of samples collected at different } \\
\text { ripening times }\end{array}$ & $\begin{array}{l}\text { PCA } \\
\text { iPLS } \\
\text { PLS }\end{array}$ & [114] \\
\hline- & $\mathrm{PEDOT} / \mathrm{Pt}$ & Red wines & Classification of different samples and origin & $\begin{array}{l}\text { PCA } \\
\text { PLS }\end{array}$ & [115] \\
\hline $\mathrm{Pt} \mathrm{Au}$ & $\mathrm{PEDOT} / \mathrm{Pt}$ & Fruit juice & Discrimination between samples from different fruits & $\begin{array}{c}\text { PCA } \\
\text { PLS-LDA }\end{array}$ & [116] \\
\hline IDE PA6/IDE & PA6/PANI/IDE (0.25-5.0\% PANI) & Bovine milk & $\begin{array}{c}\text { Discrimination of samples according to tetracycline } \\
\text { residue content }\end{array}$ & PCA & [117] \\
\hline CE AuCE rGO-CE rGO-AuCE & $\begin{array}{l}\text { PANI-CE } \\
\text { PANI-AuCE }\end{array}$ & $\begin{array}{l}\text { Vinegar, } \\
\text { sugar }\end{array}$ & Multiflavor detection & PCA & [118] \\
\hline $\begin{array}{l}\text { C/SPE NiO/C/SPE } \\
\text { MWCNT/C/SPE } \\
\text { SWCNT/C/SPE Pt }\end{array}$ & $\mathrm{PANI} / \mathrm{C} / \mathrm{SPE}$ & Red wine & Phenolic content & PCA & [119] \\
\hline $\begin{array}{l}\text { SWCNT/SPCE } \\
\text { MWCNT/SPCE }\end{array}$ & PPy-DSA/SPCE & White wine & Discrimination according to varietal origin & $\begin{array}{l}\text { PCA } \\
\text { LDA }\end{array}$ & {$[120]$} \\
\hline $\begin{array}{l}\mathrm{GdPc}_{2} / \mathrm{CSPE} \mathrm{DyPc} / \mathrm{CSPE} \\
\mathrm{CSPE}\end{array}$ & $\begin{array}{c}\text { PPy-dopant/CSPE } \\
\text { Dopant: FeCN, NP, Mo }\end{array}$ & Beef & Determination of ammonia and putresceine & $\begin{array}{c}\text { PCA } \\
\text { PLS-LDA }\end{array}$ & [122] \\
\hline- & $\begin{array}{c}\text { PPy- dopant/Pt Dopant: DSA, } \mathrm{H}_{2} \mathrm{SO}_{4}, \mathrm{FCN}, \\
\text { AQDS, PWA, TSA }\end{array}$ & Beer & Evaluation of bitterness and alcoholic strength & $\begin{array}{l}\text { PCA } \\
\text { PLS }\end{array}$ & [123] \\
\hline- & $\begin{array}{c}\text { PPy-dopant/Pt Dopant: FCN, NP, } \mathrm{PWA}^{\mathrm{H}_{2} \mathrm{SO}_{4}}, \\
\text { MO, AQS }\end{array}$ & Olive oil & Evaluation of bitterness & $\begin{array}{l}\text { PCA } \\
\text { PLS }\end{array}$ & [124] \\
\hline- & PPy-dopant/SPCE Dopant: DSA, $\mathrm{SO}_{4}, \mathrm{FCN}$ & Wine & Classification of wines according to vintage year & $\begin{array}{l}\text { PCA } \\
\text { LDA }\end{array}$ & [125] \\
\hline Graphite-epoxy PtNPs CuNPs & $\begin{array}{l}\text { PANI } \\
\text { PPy }\end{array}$ & Wine & $\begin{array}{c}\text { Classification of wines and recognition of the } \\
\text { oxygenation effect }\end{array}$ & PCA & [126] \\
\hline
\end{tabular}

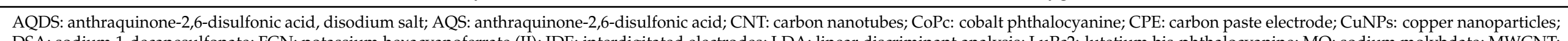

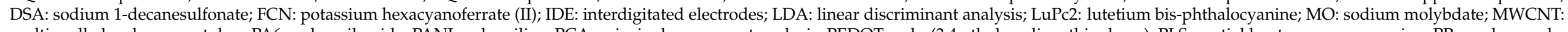

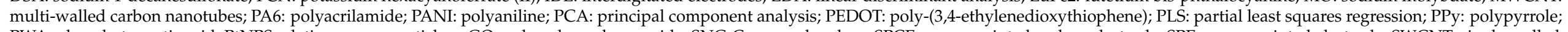

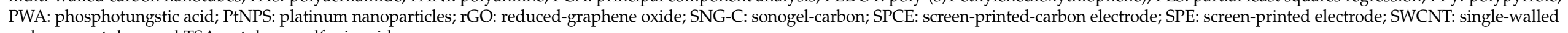
carbon nanotubes; and TSA: p-toluenesulfonic acid. 


\section{PEDOT/Pt sensor}

(a)

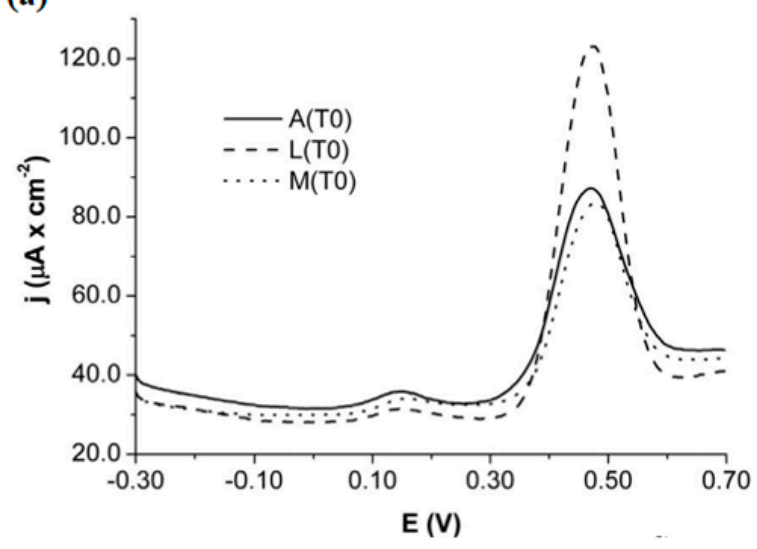

(b)

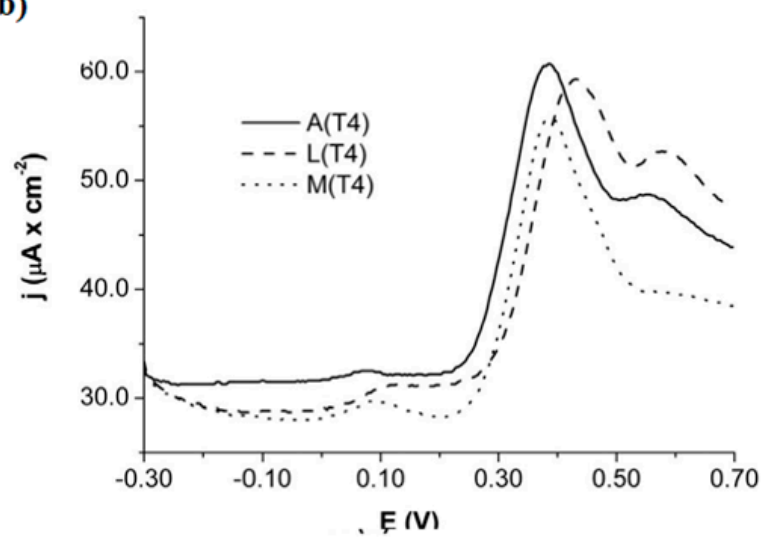

(c)

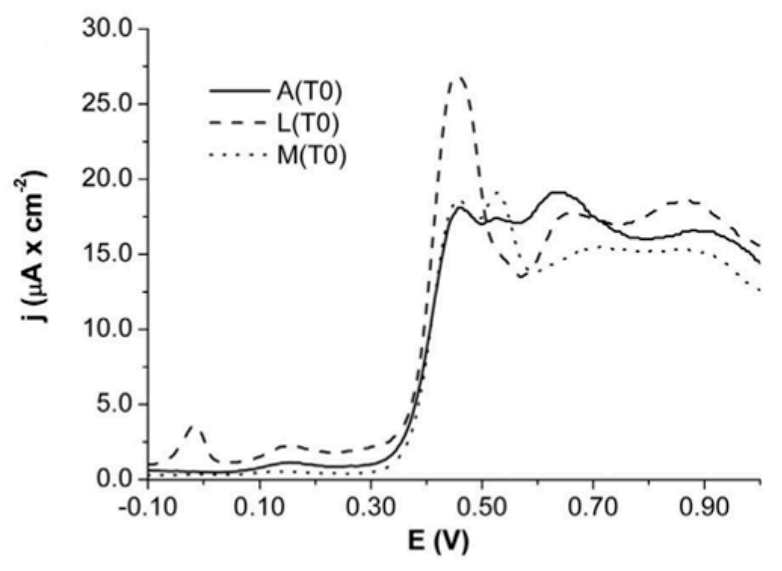

(d)

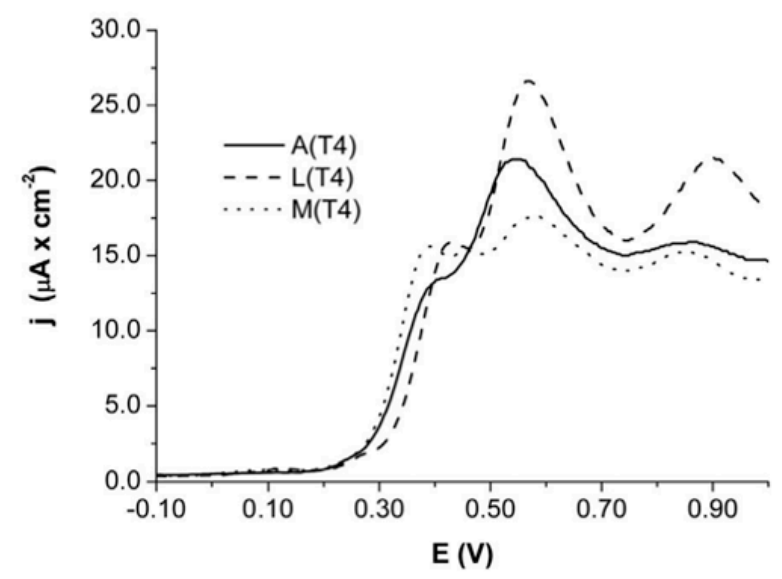

Figure 5. Voltammetric responses obtained with PEDOT/Pt $(\mathbf{a}, \mathbf{b})$ and sonogel-carbon sensors $(\mathbf{c}, \mathbf{d})$ for three types of Italian grape varieties, Ancellota (A), Lambrusco Marani (L) and Malbo Gentile (M), collected at 10 days (T0) and 50 days (T4). Reprinted with permission from ref. [114]. Copyright 2018, Elsevier.

Chemometric analysis was performed in all cases, leading to relevant conclusions. Briefly, PCA analysis allowed the clear differentiation of wines with different $\mathrm{SO}_{2}$ content. Considering that $\mathrm{SO}_{2}$ should be ranged in a specific concentration interval, samples with outlier values can be identified and, therefore, the screening of chemical adulteration in red wines can be successfully assessed [121]. Differently, Arrieta et al. studied redox processes of different alcoholic beverage samples (wine and beer). The authors employed PPy based sensor arrays to build a model able to predict $\alpha$-isoacid and alcoholic degree content by PLS method. In addition, dark beers were discriminated from pale beers and alcohol-free samples considering PCA score plots [123]. Alternately, Garcia-Hernandez et al. were also able to differentiate wine samples according to the polyphenol content studied by PANI coated sensors by means of PCA analysis. Interestingly, the analytical methodology reported in this work combines the use of the electronic tongue and the infrared spectroscopy to estimate fourteen chemical parameters of red wines in a few minutes [119]. It is noteworthy to mention the use of hybrid composites constituted by conducting polymer powders instead of coatings in electronic tongues by M. del Valle and coworkers. Graphite-epoxy resins modified with metallic, cobalt, PANI, and PPy powders were employed as voltammetric sensor arrays in qualitative and quantitative analyses of 
wines [126]. Figure 6 depicts the usual fabrication of epoxy-resin electrodes modified with CPs powders.

\section{Mixing step}

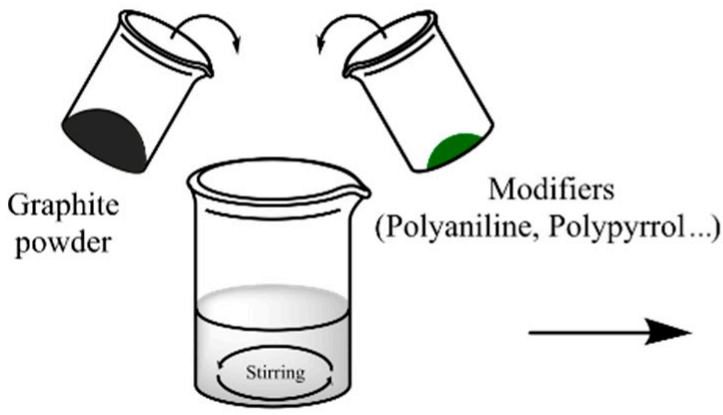

Epoxy Resin + hardener

\section{Filling step}

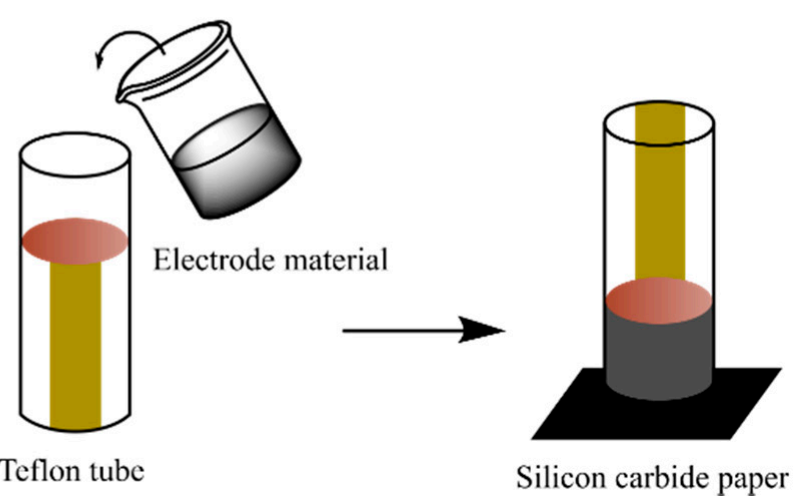

Figure 6. Fabrication of epoxy-resin electrodes modified with CPs powders.

The resulting electronic tongue was able to distinguish several types of wines [126] and cavas [127] (Figure 7), detecting undesired products from their elaboration, as well as to determine the polyphenol index of a large number of wine samples [128]. In the last report, the identification of some polyphenolic compounds using a PPy-modified sensor was also performed, opening up the possibility to quantify individual polyphenols present in a complex mixture-an issue of paramount importance for the successful assessment of antioxidant capacity — with a simple and low-time consuming analytical tool.
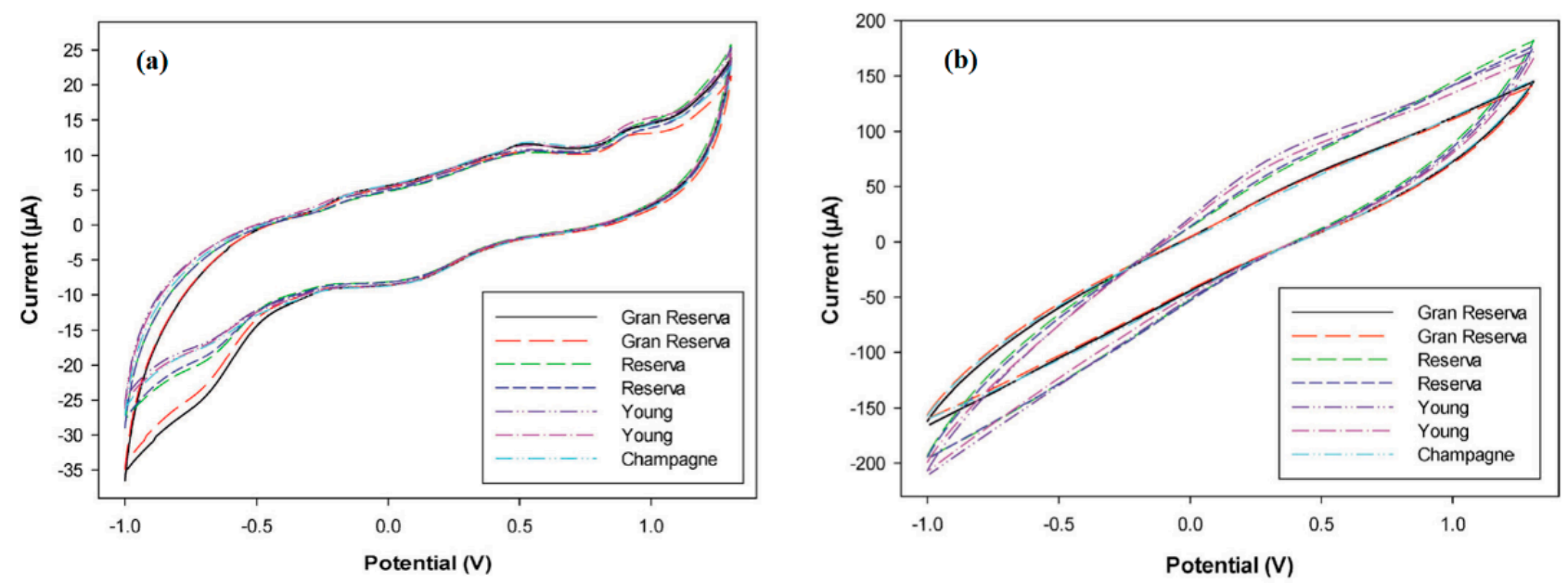

Figure 7. Cyclic voltammograms recorded with (a) PPy-graphite epoxy and (b) PANI-graphite epoxy sensors for different wine and cava samples. Adapted with permission from ref. [127]. Copyright 2014, John Wiley and Sons.

Despite the wide application of E-tongues to alcoholic beverages, other food samples have already been studied by these devices as well. For example, another PANI-based tongue mixed with polyamide was capable to discriminate several bovine milk samples based on their tetracycline content by using PCA analysis [117]. Furthermore, the residue concentration can be clearly distinguished. A polymer sulfanilic acid film (PBSA) was recently integrated in an E-tongue system capable to discriminate rice wines from different local origins targeting ascorbic acid, glucose, and tyrosine [129,130]. Additionally, 
poly-(alkoxy-bithiophenes) and polylactic acid based sensors were employed in the discrimination of diverse taste solutions [131,132].

To a lesser extent, the employment of electronic tongues based on conducting polymer coatings in environmental monitoring has also been reported. One illustrative example is the research piece of Braga et al. In this work, water samples were classified according to the 2-methylisoborneol and geosmin contents, two toxic substances derived from algae decomposition, using sensor arrays constituted by PANI layers. Moreover, the concentration of both analytes could be monitored at values as low as $25 \mathrm{ng} / \mathrm{L}$ in tap and distilled water [133]. Similarly, Carvalho et al. employed PANI coatings as working electrodes in combination with poly(o-ethoxyaniline), sulfonate lignin, and aquatic humic substances to analyze tap water. The resulting electronic tongue was able to discriminate water samples collected from diverse locations on the basis of different psychochemical parameters, such as $\mathrm{pH}$, temperature, and turbidity, among others [134]. On the other hand, Facure et al. proposed sensors arrays based on PPy and PEDOT/PSS in combination with rGO for the discrimination of two commercial pesticides, Malathion and Cadusafos. Based on PCA results reported in this work, both analytes can be distinguished at nanomolar level in buffer and tap water samples [135]. Poly(o-ethoxyaniline) and nylon 6 were used as sensing units in the determination of paraoxon in corn top. The resulting electronic tongue was capable to discern paraoxon contamination in water samples [136].

As it was mentioned in Section 1, enzymes can be immobilized into the conducting polymer coatings, enhancing the selectivity of the device. This approach has been reported in several research works, such as the incorporation of tyrosinase by the electrodeposition of PEDOT onto a sonogel-carbon surface [72] and the simultaneous electrodeposition of PPy and tyrosinase on platinum $[137,138]$. Particularly, C. Garcia-Hernandez and coworkers developed a bio-electronic tongue containing both tyrosinase and glucose oxidase enzymes with PPy films doped with gold nanoparticles collectively deposited onto platinum and stainless-steel substrates. The resulting devices were able to predict total polyphenol index and sugars of grapes using chemometric analysis based on the specificity provided by the biological recognition elements towards polyphenols and sugars. Additionally, the polyphenol index and the alcoholic degree of wines were also predicted [139].

The effect of nanostructured surface morphology on the sensing behavior should also be considered. For instance, PEDOT nanorods were deposited on a glassy carbon surface and applied for electrochemical detection of nitrite, exhibiting high sensitivity due to the good dispersibility and large surface area [140]. Other work reported the deposition of PEDOT nanorods and graphene oxide sheets (GO) on glassy carbon. The resulting electrochemical sensor displayed the best sensitivity with PEDOT/GO for rutin detection compared with the bare device or those modified with PEDOT or GO. This result can be attributed to the high surface area, which provides a high number of active sites to increase the electron transfer between the analyte and electrode [141]. Another work studied the influence of film thickness on the electrochemical performance using interdigitated microelectrodes based on poly(o-ethoxyaniline). The sensitivity was increased with the thickness of the film, which can be ascribed to higher roughness morphology [142]. Another scientific work reported the development of cobalt oxide nanosheets embedded with PANI nanofibers and employed as biosensors for glucose oxidation. The thickness of the conducting film on cobalt nanosheets plays a relevant role: an increased thickness of PANI resulted in a long diffusion layer between the electrolyte and the surface, making the analyte/surface electron transfer difficult. On the other hand, lesser film thickness may contain a low number of active sites, leading to lower oxidation current values. For these reasons, the thickness of PANI was optimized with the aim to obtain an electrochemical device with a remarkable electrochemical performance [77]. 


\section{Electronic Noses (E-Noses) Based on CPs}

\subsection{Sensing Unit: Chemiresistors}

In principle, three types of sensing units can be employed in gas sensing: chemiresistors, quartz crystal microbalance gravimetry, and optical sensors [143]. Among all of them, the first one is, by far, the most employed unit in electronic noses, and thus, this review will be focused on chemiresistors as the sensing unit.

The sensing performance of chemiresistor-based conducting polymers has been widely reported in bibliography. In brief, after exposing the conducting film to gases, the resistance changes depending on the initial concentration of the flowing gas. The overall resistance (S) measured with the p-doped polymeric device was calculated by the ratio between the resistance in air $\left(\mathrm{R}_{\mathrm{a}}\right)$ and the resistance in the presence of the flowing gas $\left(\mathrm{R}_{\mathrm{g}}\right)$ by using the following equation [144].

$$
\mathrm{S}=\frac{\left|\mathrm{R}_{\mathrm{g}}-\mathrm{R}_{\mathrm{a}}\right|}{\mathrm{R}_{\mathrm{a}}} \times 100
$$

The sensing mechanism of $\mathrm{p}$-doped conducting polymers towards different pollutants is overviewed in several review papers [145-148] and shown in Figure 8. The target gas can act as an electron donor of the conducting polymer layer, leading to a decrease in the number of holes by electron-hole combination, and thus, increase the charge resistance. On the other hand, electrons from the conducting band of the polymer can be removed by an electron-acceptor compound, leading to the increase in the number of holes, and, hence, decrease the electrical resistance.

(a)

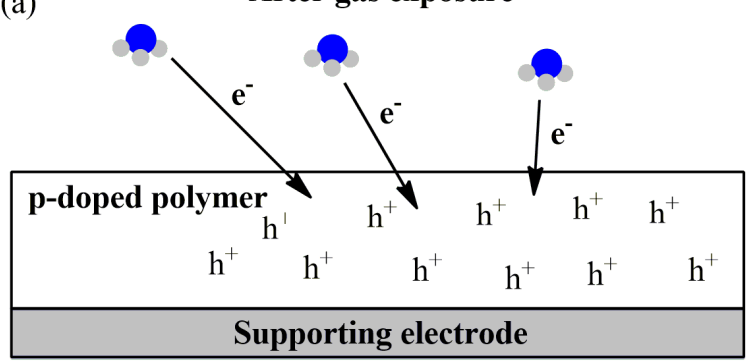

Reduction of charge carriers by electron-hole combination

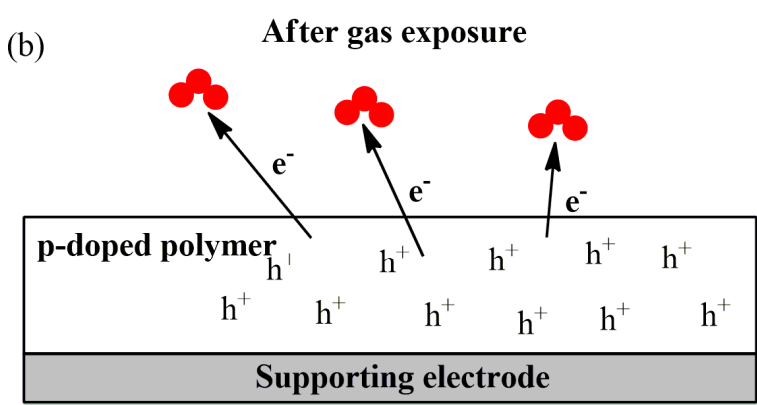

Increase of number of holes due to the removal of electrons located in the conducting band

Figure 8. Overall mechanism of gas sensing using a reducing gas $\left(\mathrm{NH}_{3}\right)(\mathbf{a})$ and an oxidant gas $\left(\mathrm{O}_{3}\right)(\mathbf{b})$ as examples.

The p-doped polymer resistance changes depending on the nature of the target analyte: oxidant gases, such as $\mathrm{NO}_{2}$ and $\mathrm{O}_{3}$, induce an increase in the number of major charge carriers, decreasing the resistance (Figure $8 \mathrm{~b}$ ). Reducing gases, such as $\mathrm{NH}_{3}, \mathrm{CO}$, and $\mathrm{H}_{2} \mathrm{~S}$, induce the opposite effect by decreasing the charge carriers of the conducting film (Figure 8a) [149].

The protonation/deprotonation of the conducting layer due to the vapor exposure is also reported in the literature for some conducting polymers, such as PANI [150-152]. Figure 9 illustrates a possible interaction between ammonia, a reducing gas widely employed as model analyte, and PANI.

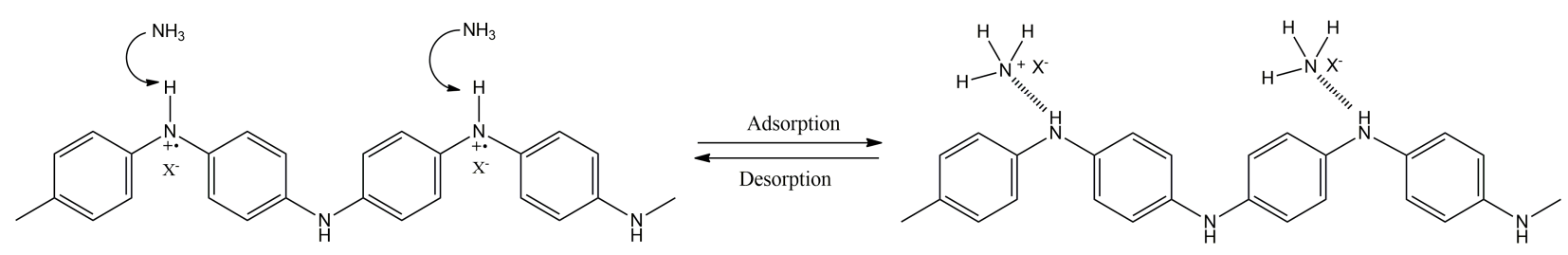

Figure 9. Possible interaction mechanism between ammonia and PANI. 
As it can be observed in the previous figure, PANI can be deprotonated under ammonia exposure, leading to the de-doped state of PANI. This process is reversible, and thus, PANI can be protonated again, leading to the desorption of ammonia. The performance of some chemiresistors based on conducting polymers, in terms of concentration detected, response and recovery times, are shown in Table 3.

Table 3. Chemiresistors based on polythiophene (PTh), poly-(3,4-ethylenedioxythiophene) (PEDOT), polyaniline (PANI), and polypyrrole (PPy).

\begin{tabular}{|c|c|c|c|c|c|c|}
\hline \multirow[b]{2}{*}{ Gas Sensor Device } & \multirow[b]{2}{*}{ Target Gas } & \multirow[b]{2}{*}{ Range (ppm) } & \multicolumn{3}{|c|}{ Sensing Performance } & \multirow[b]{2}{*}{ Ref. } \\
\hline & & & $\begin{array}{c}\text { Gas Conc. } \\
(\mathrm{ppm})\end{array}$ & $\begin{array}{l}\text { Recovery Time } \\
\text { (s) }\end{array}$ & $\begin{array}{c}\text { Response Time } \\
\text { (s) }\end{array}$ & \\
\hline $\mathrm{SnO}_{2} / \mathrm{PTh}$ & $\mathrm{NO}_{2}$ & 10-200 & 10 & - & 2.07 & [153] \\
\hline $\mathrm{P} 3 \mathrm{CT} / \mathrm{CNT}$ & NMPEA & $0.004-0.032$ & 0.004 & 40 & 20 & [154] \\
\hline PEDOT:PSS $/ \mathrm{FeCl}_{3}$ & $\mathrm{NH}_{3}$ & $0.2-200$ & 0.5 & - & 20 & [155] \\
\hline $\mathrm{WO}_{3}$-PEDOT:PSS & LPG & $500-3000$ & 500 & 54 & 29.4 & [156] \\
\hline PANI/PVDF & $\mathrm{NH}_{3}$ & $0.2-5$ & 0.2 & 235 & 174 & [157] \\
\hline $\mathrm{PANI} / \mathrm{SnO}_{2}$ & $\mathrm{NO}_{2}$ & $5-55$ & 37 & 25 & 17 & [158] \\
\hline $\mathrm{SnO}_{2} / \mathrm{rGO} / \mathrm{PANI}$ & $\mathrm{H}_{2} \mathrm{~S}$ & $0.05-10$ & 2 & 78 & 82 & [159] \\
\hline PANI-NF & LPG & $100-1000$ & 700 & 200 & 50 & [160] \\
\hline $\mathrm{PPy} / \mathrm{rGO}$ & $\mathrm{NH}_{3}$ & $1.0-4.0$ & 1.0 & 300 & 60 & [161] \\
\hline PPy thin film & $\mathrm{NO}_{2}$ & $10-100$ & 10 & 374 & 218 & [162] \\
\hline PPy nanoribbons & $\mathrm{CH}_{3} \mathrm{CH}_{2} \mathrm{OH}$ & - & 100 & 31 & 2 & [163] \\
\hline PPy-Ag & $\mathrm{CH}_{3} \mathrm{COCH}_{3}$ & $25-600$ & 580 & 150 & 175 & [164] \\
\hline PPy-CNT & $\mathrm{H}_{2}$ & $1-100$ & 10 & - & $>1.0$ & [165] \\
\hline
\end{tabular}

CNT: carbon nanotubes; LPG: liquified petroleum gas; NF: nickel ferrite; NMPEA: n-methylphenethylamine; P3CT: poly[3 -(6-carboxyhexyl)thiophene-2,5-diyl]; PANI: polyaniline; PEDOT: poly-(3,4-ethylenedioxythiophene); PPy: polypyrrole; PSS: poly(styrenesulfonate); PTh: polythiophene; PVDF: polyvinylidene; and r-GO: reduced-graphene oxide.

Upon scrutiny of Table 3, it is possible to note that several volatile compounds can be detected using gas sensors comprised by conducting polymers. Remarkably, low recovery and response times were obtained in all cases, as well as negligible influence of humidity in some cases, indicating good sensing performance [161]. Another example regarding the employment of PANI-based flexible devices for the gas sensing of several volatile biomarkers can be found in the work published by Deng et al. [166]. In this work, high tolerance of this sensor to the humidity at room temperature was reported. Therefore, it becomes apparent that the employment of conducting polymers to constitute electronic noses for volatile compounds detection is feasible and highly recommended.

\subsection{Analytical Application of E-Noses}

Among the multiple possible applications of E-noses, the early diagnosis of diseases and the evaluation of food quality in a non-invasive manner are the most relevant for society. Importantly, electronic nose devices based on conducting nanocomposites have proved their suitability in both scenarios during the last decade [167-170].

Despite its high interest currently, investigations of the role of conducting polymers in electronic noses started in the previous century, with the development of PPy, PTh, and PANI derivatives to detect alcoholic volatile compounds [171]. However, new discoveries have been carried out at the beginning of this century, leading to great improvements in the development of these devices. In this regard, Stella and coworkers developed an E-nose system based on PEDOT, PANI, and PPy coatings for the distinction of three Italian olive oils by using their aromatic substances content as a differentiating parameter [172]. Contrarily, other authors have vastly explored the role of several dopants. For example, Barisci et al. developed gold tracks supported on silicon chip coated with PPy doped with 12 different chemical compounds to detect aromatic hydrocarbons, benzene, toluene, ethylbenzene, and xylene [173]. In spite of the lack of concise explanations, the authors must be praised 
for the wide spectrum of polymers assayed. In fact, the evaluation of different dopants in CPs seems to be the quintessence of a great number of pieces of research. Particularly, PANI coatings with different doping agents are commonly reported in bibliography as sensor arrays in E-nose devices to monitor several parameters in foodstuffs and human body fluids [174-176]. Table 4 shows some illustrative examples recently reported in the literature.

Table 4. Electronic noses based on polyaniline (PANI) films applied for analytical purposes in the last decade.

\begin{tabular}{|c|c|c|c|c|}
\hline PANI Sensor Array & Sample & Use & Multivariate Calibration & Ref. \\
\hline $\begin{array}{c}\text { PANI-dopant/IDGEs } \\
\text { Dopant: CSA, DBSA, HCl }\end{array}$ & $\begin{array}{l}\text { Strawberry } \\
\text { Grape } \\
\text { Apple }\end{array}$ & $\begin{array}{l}\text { Discrimination of samples } \\
\text { according to aromatic } \\
\text { substances }\end{array}$ & PCA & [177] \\
\hline $\begin{array}{l}\text { PANI-HCl/PGIEs } \\
\text { PANI-HCl/IDEs }\end{array}$ & $\begin{array}{l}\text { Strawberry } \\
\text { Grape } \\
\text { Apple }\end{array}$ & Detection of different aromas & PCA & [178] \\
\hline $\begin{array}{c}\text { PANI-dopant/IDGEs } \\
\text { Dopant: HCl, TSA, CSA, } \\
\text { MSA }\end{array}$ & Cow's estrus & $\begin{array}{l}\text { Determination of estrus } \\
\text { times of cows }\end{array}$ & PCA & [179] \\
\hline $\begin{array}{c}\text { PANI-dopant/IDEs } \\
\text { Dopant: HCl, TSA, CSA, } \\
\text { MSA }\end{array}$ & Bananas & $\begin{array}{l}\text { Monitoring of bananas } \\
\text { ripeness }\end{array}$ & PCA & [180] \\
\hline $\begin{array}{c}\text { PANI-dopant/PGIEs } \\
\text { Dopant: CSA, HCl, DBSA }\end{array}$ & Gummy candies & $\begin{array}{l}\text { Monitoring of aromas during } \\
\text { candy storage }\end{array}$ & PCA & [181] \\
\hline $\begin{array}{c}\text { PANI-CSA/Chitosan } \\
\text { PANI-DBSA/ } \mathrm{TiO}_{2} \\
\text { PANI-DBSA/CNT }\end{array}$ & $\begin{array}{l}\text { Simulated human } \\
\text { breath }\end{array}$ & $\begin{array}{l}\text { Preliminary diagnoses of } \\
\text { kidney disease }\end{array}$ & $\begin{array}{l}\text { PCA } \\
\text { LDA }\end{array}$ & [182] \\
\hline PANI/AuNPs & Human breath & $\begin{array}{l}\text { Early diagnoses of renal } \\
\text { diseases }\end{array}$ & $\begin{array}{l}\text { PCA } \\
\text { LDA }\end{array}$ & [183] \\
\hline $\begin{array}{c}\text { PANI-dopant/MWCNT } \\
\text { PANI-dopant/GO } \\
\text { Dopant: CSA, DBSA, HCl }\end{array}$ & Essential oils & $\begin{array}{l}\text { Determination of quality of } \\
\text { essential oils }\end{array}$ & PCA & [184] \\
\hline
\end{tabular}

CSA: camphorsulfonic acid; DBSA: dodecylbenzenesulfonic acid; GO: graphene oxide; IDE: interdigitated electrode; MSA: methanesulfonic acid; MWCNT: multi-walled carbon nanotubes; PANI: polyaniline; and TSA: p-toluene sulfonic acid.

The electrochemical performance of electronic noses based on PANI is reported in the previous table. As observed, there is a vast exploitation of dopant agent employment for the preparation of PANI sensors in all ambits. The research performed by Tiggemann et al. in this field proposing a PANI film doped with CSA deposited on PGIE (PANI-CSA/PGIE) should be praised. The resulting film was extensively characterized by SEM and proved that it led to faster response and high sensitivity for strawberry and apple in comparison with PANI-HCl/PGIE and PANI-DBSA/PGIE, with less porous and homogeneous surfaces. Interestingly, it was also demonstrated that porous morphology allows the flowing of the target gas into the substrate, facilitating gas diffusion and hence, increasing the detection rate [181]. Additionally, it was stated that the interaction between the volatile compound and the conducting polymer surface also plays an important role in the sensitivity displayed with the sensor. In the same report, higher sensitivity for grape aromas was achieved with PANI-HCl/PGIE film compared with those obtained with PANI-CSA/PGIE and PANI-DBSA/PGIE under the same conditions. This can be justified based on a favorable interaction between PANI-HCl/PGIE surface, homogeneous and regular, and volatiles with bulky groups, such as methyl anthranilate ester, commonly found in grape aromas. Other authors have drawn similar conclusions. For example, the higher resistance variation found with the PANI/chitosan sensor reported by Maout and coworkers can be also explained in terms of coating morphology. In this case, PANI clusters were embedded into the insulating chitosan matrix at different depths, providing higher resistive responses [182]. 
Furthermore, the morphology of carbon allotrope/PANI surface was also studied for gas sensing of different essential oils. The rougher morphology appreciated in PANI/GO surfaces led to faster interaction with volatile organic compounds (VOCs) with respect to PANI/MWCNT surfaces [184].

Despite the wide use of PANI films in E-noses, the employment of PTh derivatives and PPy coatings in E-nose arrays should be stressed as well. In this regard, discrimination of some VOCs was carried out using an E-nose system based on hybrid PEDOT/graphene films arrays. Tung et al. reported a dual doping role of VOCs: by controlling the carrier mobility in graphene layers and by inducing a conformational change of PEDOT chains. Moreover, a synergistic effect between graphene and PEDOT was described in this work, yielding high electrical performance [185]. Other work reported the employment of PPy coatings doped with several counter anions in the discrimination of VOCs and the sensing of several alcoholic compounds [186,187], highlighting the role of the morphology of polymer coating in the responses collected from each sensor. Alternatively, poly (3-hexylthiophene) and poly(9,9-n-octyl-2,7-fluorenylenevylene-alt-4,7-dibenzothiadiazole2,5-thiophene) (PF-TBT) were used in E-nose for the detection of several gases, used as biomarkers for diseases and environmental monitoring [188] and for the discernment of tobacco samples, in combination with diverse porphyrins [189], respectively. Another polyvinyl derivative, (poly[2-methoxy-5-(2- ethylhexyloxy)-1,4-phenylenevinylene)] (MEHPPV), was used as the active layer with a porous silicon structure for $\mathrm{NO}_{2}$ gas sensing. Based on its promising analytical performance, it can be applied as an E-nose for environmental monitoring [190]. A recent work published by Jafari and Amini reported a PPy electrochemical device as a promising sensing unit for an E-nose system to detect lactic acid gas [191].

On the other hand, Rañola et al. have focused their efforts on research involving CPs composite materials in the analysis of oil samples. In this case, poly(3-methylthiophene) was employed together with PANI and PPy sensors to discriminate different virgin coconut oil samples. After using PCA analysis, rancid coconut oil could be easily distinguished from refined ones [192].

Other foodstuffs can be analyzed using E-nose devices based on CP composites. An Enose containing several ethylene and vinylene derivatives was employed in the evaluation of the biodeterioration of oranges by fungus species. Differences between oranges after the first day of incubation and those non-inoculated (control oranges) were established by means of PCA analysis. Interesting findings were obtained with the device, since the color of oranges slightly changed after the first day of incubation compared with the control group; thus, visual differences between both groups were not found, in contrast with significant differences obtained with the E-nose system [193].

Even if E-noses are more devoted to foodstuff or environmental analysis, there are some researchers that try to promote them in the health sector as well. An interesting piece of research was exhibited by Castro and coworkers reporting an E-nose based on different polymer matrices and MWCNTs as a lung cancer biomarker detector for the discrimination of several organic vapor solvents (toluene, methanol, ethanol, and water vapor, among others) using PCA analysis [194]. Additionally, other authors have proposed a carbon transducer based on poly (ether-imide) as a cancer biomarker for the detection of several solvents. In this work, it was demonstrated that the aromatic bulky pendant groups in the polymeric layer established strong attractions with the CNT surfaces, which allow the creation of active sites where analyte molecules are adsorbed, improving the sensitivity of the device [195].

As in the case of electronic tongues based on conducting polymers, the presence of nanostructures can improve the performance of E-noses. A critical review regarding the employment of nanostructured materials for gas sensing was offered in the previous decade [196]. A chemiresistor constituted by a PEDOT nanocomposite exhibited excellent sensitivity and selectivity for $\mathrm{NO}_{2}$ detection, which can be explained by the enhancing of gas sorption/desorption due to its porous nanostructured surface [197]. PPy nanoparticles 
were employed for sensing of ammonia and methanol vapor gases. Regardless of the analyte, sensitivity was increased at lower particle size of PPy. Furthermore, the device composed of PPy nanoparticles provided low response and recovery times [198]. Other examples of the influence of nanostructures for gas sensing can be found in the work published by Ma and coworkers. In this work, porous nanostructures of PANI allow a sensitive detection of amines, proposing an extensive gas sensing mechanism [199]. Another work reported the sensing of acetone with a poly-(3-hexylthiophene) nanofibers sensor [200]. Fast rise time was obtained with this device, which can be ascribed to the high number of sites for gas/material interaction available to the analyte along the nanofiber.

\section{Future Perspectives: Integration of E-Tongues and E-Noses in Commercial Systems}

It is not ambitious to think that the analytical applications of E-tongues/noses possess a great impact, not only in the foodstuff ambit but also in the health and environmental sector. Furthermore, this impact is rising sharply, reflecting the great need in society for these devices. Therefore, their implementation in commercial devices is exceedingly pursued by many sensor companies. Currently, there are some examples of its commercialization.

\subsection{Commercial Prototypes of E-Tongues}

Concerning E-tongues, Alpha M.O.S (Tolouse, France) and Insent Inc (Kanagawa, Japan) offer two models ( $\alpha$ Astree and TS-5000Z, respectively) that have been used in the evaluation of food quality in the last decade [201-205]. Other laboratory prototypes were also employed for pharmaceutical analysis, providing very satisfactory results like those obtained with commercial systems [206].

\subsection{Commercial Prototypes of E-Noses}

Regarding E-noses, a commercial system containing several conducting polymers as sensor arrays (Cyranose $320^{\circledR}$ ), offered by Sensigent (California, USA), was employed in the screening of several diseases (breast and lung cancer [207-209], asthma [210,211], and amyotrophic lateral sclerosis [212], among others), identification of foodstuffs (rice, wines [213], and fruits [214]) and classification of road asphalt samples [215,216]. Additionally, fecal VOCs can be inspected as well, informing about the microbial enterotype of infants [217]. Other companies also supply E-noses. For example, AromaScan A32S ${ }^{\circledR}$ (Osmetech Inc. London, UK) provides useful information about the diagnosis of urban trees, being able to discriminate VOCs from healthy and decaying woody samples [218], and the assessment of the quality of catfish meat [219]. In this work, off-flavor in catfish filets can be identified from good-flavor ones by means of PCA. Notably, the new device tested displayed promising features for the analysis of commercial beverages [220].

\subsection{Final Remarks: Challenges of Electrochemical/Gas Sensing Devices}

Despite the excellent analytical results provided at laboratory scale in food, pharmaceutical, and medical sectors, only some timid examples can be found commercially available. In our modest opinion, the inclusion of CPs and their development may pave the way to keep growing and reach the desired applicability of E-tongue and E-nose systems. Currently, in order to reach higher technological readiness levels (TRLs), the developed devices must be able to perform reliable, robust, fast, accurate, and in-situ measurements using diverse samples, by using a non-complex, low cost, and portable instrumentation. The stability of the conducting coatings is another issue to take into account, since the repeatability of the responses provided with the devices can be affected. The conducting film may be passivated after performing successive electrochemical assays, and film overoxidation can take place at high potentials as well. Furthermore, stability can be affected by swelling/deswelling phenomena. With the aim to minimize these factors, several parameters, including analyte concentration, film characteristics (e.g., thickness and morphology) and instrumental conditions should be carefully controlled. Further research in this sense is under study to accomplish all the commercial requirements mentioned. 


\section{Conclusions}

The analytical utility of E-tongues and E-noses containing intrinsic conducting polymers for analytical monitoring purposes has been briefly overviewed. E-tongues demonstrate their usefulness in important areas of food industry, such as chemical adulteration, classification of foodstuffs, determination of polyphenol indexes, bitterness evaluation, etc. The use of voltammetric sensor arrays and their combination with spectroscopic techniques provide useful information of the sample, as can be found in some works collected in this review. Other sectors can be encompassed with these devices, i.e., environmental monitoring. Hybrid conducting polymer composites based on epoxy resins can be also used as sensor arrays, displaying several advantages, such as renewable electrode surface and stability in different solvents. Contrarily, E-tongues can be also constituted by enzymatic sensors, which provides selectivity for the analysis of sugars and polyphenols, among others. On the other hand, E-noses are employed in foods and body fluids, being useful in food quality and diagnosis of several diseases. The electrochemical performance of the $\mathrm{CP}$ sensor arrays is affected by the conducting coating morphology, as was previously discussed. The interaction between polymer electrode surface and target volatile compounds also plays a key factor in the analytical performance of the E-nose. Based on the above, conducting polymer based-electronic systems are promising for analytical purposes in the in-situ screening of several adulterations and diseases, providing reliable and accurate results extremely fast. Major attention in the development of commercial electronic tongues and noses will be focused on future investigations, allowing in situ monitoring of several features of target samples.

Author Contributions: Conceptualization, D.L.-I., J.M.P.-S. and L.C.-A.; methodology and investigation, A.S.-P., J.J.G.-G. and D.L.-I.; writing-original draft preparation, A.S.-P., J.J.G.-G. and D.L.-I.; writing - review and editing, all; supervision, J.M.P.-S. and L.C.-A. All authors have read and agreed to the published version of the manuscript.

Funding: This research received no external funding.

Institutional Review Board Statement: Not applicable.

Informed Consent Statement: Not applicable.

Data Availability Statement: Not applicable.

Acknowledgments: Juan José García-Guzmán thanks Instituto de Investigación Biomédica de Cádiz (INiBICA) for his post-doctoral contract. Alfonso Sierra-Padilla greatly acknowledges ESF funds, Sistema de Garantía Juvenil depending on Ministerio de Empleo y Seguridad Social of Spain and Junta de Andalucía for his employment contract. The authors also thank Junta de Andalucia (PAIDI2020), Institute of Research on Electron Microscopy and Materials (IMEYMAT, Polybiosens project), and Programa de Fomento e Impulso de la Investigación y de la Transferencia de la Universidad de Cádiz 2020-202' for the project PR2020-013 (Proyectos de Investigación-Puente 2020).

Conflicts of Interest: The authors declare no conflict of interest.

\section{References}

1. Hryniewicz, B.; Orth, E.; Vidotti, M. Enzymeless PEDOT-based electrochemical sensor for the detection of nitrophenols and organophosphates. Sens. Actuators B Chem. 2018, 257, 570-578. [CrossRef]

2. Shoaie, N.; Daneshpour, M.; Azimzadeh, M.; Mahshid, S.; Khoshfetrat, S.M.; Jahanpeyma, F.; Gholaminejad, A.; Omidfar, K.; Foruzandeh, M. Electrochemical sensors and biosensors based on the use of polyaniline and its nanocomposites: A review on recent advances. Microchim. Acta 2019, 186, 465. [CrossRef] [PubMed]

3. Rahman, A.; Kumar, P.; Park, D.-S.; Shim, Y.-B. Electrochemical sensors based on organic conjugated polymers. Sensors 2008, 8, 118-141. [CrossRef] [PubMed]

4. Wong, Y.C.; Ang, B.C.; Haseeb, A.S.M.A.; Baharuddin, A.A.; Wong, Y.H. Review-Conducting polymers as chemiresistive gas sensing materials: A review. J. Electrochem. Soc. 2019, 167, 037503. [CrossRef]

5. Lin, Y.; Zhao, Y.; Xin, Q.; Jiang, C.; Song, A. Electrical control of the optical dielectric properties of PEDOT:PSS thin films. Opt. Mater. 2020, 108, 110435. [CrossRef]

6. Ahad, I.Z.M.; Harun, S.W.; Gan, S.N.; Phang, S.W. Polyaniline (PAni) optical sensor in chloroform detection. Sens. Actuators B Chem. 2018, 261, 97-105. [CrossRef] 
7. Alqarni, S.A.; Hussein, M.A.; Ganash, A.A.; Khan, A. Composite material-based conducting polymers for electrochemical sensor applications: A mini review. BioNanoScience 2020, 10, 351-364. [CrossRef]

8. Greco, F.; Zucca, A.; Taccola, S.; Menciassi, A.; Fujie, T.; Haniuda, H.; Takeoka, S.; Dario, P.; Mattoli, V. Ultra-Thin conductive free-standing PEDOT/PSS nanofilms. Soft Matter 2011, 7, 10642-10650. [CrossRef]

9. Chen, R.; Chen, S.; Zhou, Y.; Wei, Z.; Wang, H.; Zheng, Y.; Li, M.; Sun, K.; Li, Y. Unsubstituted polythiophene film deposited via In-Situ sequential solution polymerization for chemo-/electrochromism. Macromolecules 2020, 53, 4247-4254. [CrossRef]

10. Chen, R.; Sun, K.; Zhang, Q.; Zhou, Y.; Li, M.; Sun, Y.; Wu, Z.; Wu, Y.; Li, X.; Xi, J.; et al. Sequential solution polymerization of poly(3,4-ethylenedioxythiophene) using $\mathrm{V}_{2} \mathrm{O}_{5}$ as oxidant for flexible touch sensors. iScience 2019, 12, 66-75. [CrossRef]

11. Tsakova, V.; Seeber, R. Conducting polymers in electrochemical sensing: Factors influencing the electroanalytical signal. Anal. Bioanal. Chem. 2016, 408, 7231-7241. [CrossRef] [PubMed]

12. Zhou, K.; Dai, K.; Liu, C.; Shen, C. Flexible conductive polymer composites for smart wearable strain sensors. SmartMat 2020, 1. [CrossRef]

13. Qian, Y.; Ma, C.; Zhang, S.; Gao, J.; Liu, M.; Xie, K.; Wang, S.; Sun, K.; Song, H. High performance electrochemical electrode based on polymeric composite film for sensing of dopamine and catechol. Sens. Actuators B Chem. 2018, 255, 1655-1662. [CrossRef]

14. Mishra, A.K. Conducting polymers: Concepts and applications. J. At. Mol. Condens. Nano Phys. 2018, 5, 159-193. [CrossRef]

15. Balint, R.; Cassidy, N.J.; Cartmell, S.H. Conductive polymers: Towards a smart biomaterial for tissue engineering. Acta Biomater. 2014, 10, 2341-2353. [CrossRef]

16. Le, T.-H.; Kim, Y.; Yoon, H. Electrical and electrochemical properties of conducting polymers. Polymers 2017, 9, 150. [CrossRef]

17. Tertis, M.; Florea, A.; Săndulescu, R.; Cristea, C. Carbon based electrodes modified with horseradish peroxidase immobilized in conducting polymers for acetaminophen analysis. Sensors 2013, 13, 4841-4854. [CrossRef]

18. Yildiz, H.B.; Çalışkan, S.; Kamaci, M.; Caliskan, A.; Yilmaz, H. l-Dopa synthesis catalyzed by tyrosinase immobilized in poly(ethyleneoxide) conducting polymers. Int. J. Biol. Macromol. 2013, 56, 34-40. [CrossRef] [PubMed]

19. Jugović, B.; Grgur, B.; Antov, M.; Knežević-Jugović, Z.; Stevanović, J.; Gvozdenović, M. Polypyrrole-Based enzyme electrode with immobilized glucose oxidase for electrochemical determination of glucose. Int. J. Electrochem. Sci. 2016, 11, 1152-1161.

20. Pathiranage, T.M.S.K.; Dissanayake, D.S.; Niermann, C.N.; Ren, Y.; Biewer, M.C.; Stefan, M.C. Role of polythiophenes as electroactive materials. J. Polym. Sci. Part A Polym. Chem. 2017, 55, 3327-3346. [CrossRef]

21. Groenendaal, L.; Zotti, G.; Aubert, P.-H.; Waybright, S.; Reynolds, J. Electrochemistry of poly(3,4-alkylenedioxythiophene) derivatives. Adv. Mater. 2003, 15, 855-879. [CrossRef]

22. Zanardi, C.; Terzi, F.; Seeber, R. Polythiophenes and polythiophene-based composites in amperometric sensing. Anal. Bioanal. Chem. 2012, 405, 509-531. [CrossRef]

23. Xu, G.; Jarjes, Z.A.; Desprez, V.; Kilmartin, P.; Travas-Sejdic, J. Sensitive, selective, disposable electrochemical dopamine sensor based on PEDOT-modified laser scribed graphene. Biosens. Bioelectron. 2018, 107, 184-191. [CrossRef] [PubMed]

24. Sun, D.; Li, H.; Li, M.; Li, C.; Dai, H.; Sun, D.; Yang, B. Electrodeposition synthesis of a NiO/CNT/PEDOT composite for simultaneous detection of dopamine, serotonin, and tryptophan. Sens. Actuators B Chem. 2018, 259, 433-442. [CrossRef]

25. Guzmán, J.J.G.; Aguilera, L.C.; Milla, D.B.; Rodríguez, I.N.; Lete, C.; Palacios-Santander, J.M.; Lupu, S. Development of SonogelCarbon based biosensors using sinusoidal voltages and currents methods. Sens. Actuators B Chem. 2018, 255, 1525-1535. [CrossRef]

26. Lupu, S.; Lete, C.; Balaure, P.C.; Caval, D.I.; Mihailciuc, C.; Lakard, B.; Hihn, J.-Y.; Del Campo, F.J. Development of amperometric biosensors based on nanostructured tyrosinase-conducting polymer composite electrodes. Sensors 2013, 13, 6759-6774. [CrossRef]

27. Çetin, M.Z.; Camurlu, P. An amperometric glucose biosensor based on PEDOT nanofibers. RSC Adv. 2018, 8, 19724-19731. [CrossRef]

28. Beygisangchin, M.; Rashid, S.A.; Shafie, S.; Sadrolhosseini, A.; Lim, H. Preparations, properties, and applications of polyaniline and polyaniline thin films-A review. Polymers 2021, 13, 2003. [CrossRef]

29. Zhang, H.; Wang, J.; Gao, X.; Wang, Z.; Wang, S. The electrochemical activity of polyaniline: An important issue on its use in electrochemical energy storage devices. Synth. Met. 2014, 187, 46-51. [CrossRef]

30. Kashyap, R.; Kumar, R.; Kumar, M.; Tyagi, S.; Kumar, D. Polyaniline nanofibers based gas sensor for detection of volatile organic compounds at room temperature. Mater. Res. Express 2019, 6, 1150d3. [CrossRef]

31. Kelly, F.M.; Meunier, L.; Cochrane, C.; Koncar, V. Polyaniline: Application as solid state electrochromic in a flexible textile display. Displays 2013, 34, 1-7. [CrossRef]

32. Nate, Z.; Gill, A.A.; Chauhan, R.; Karpoormath, R. Polyaniline-cobalt oxide nanofibers for simultaneous electrochemical determination of antimalarial drugs: Primaquine and proguanil. Microchem. J. 2021, 160, 105709. [CrossRef]

33. Zhao, X.; Bai, W.; Yan, Y.; Wang, Y.; Zhang, J. Core-Shell self-doped polyaniline coated metal-organic-framework (SPAN@UIO-66$\mathrm{NH}_{2}$ ) screen printed electrochemical sensor for $\mathrm{Cd}^{2+}$ ions. J. Electrochem. Soc. 2019, 166, B873-B880. [CrossRef]

34. Sanchis, C.; Ghanem, M.; Salavagione, H.; Morallón, E.; Bartlett, P. The oxidation of ascorbate at copolymeric sulfonated poly(aniline) coated on glassy carbon electrodes. Bioelectrochemistry 2011, 80, 105-113. [CrossRef]

35. Masdarolomoor, F.; Hajizadeh, S.; Chamjangali, M.A.; Innis, P.C. Novel approach to the synthesis of polyaniline possessing electroactivity at neutral pH. Synth. Met. 2019, 250, 121-130. [CrossRef]

36. Ullah, H.; Shah, A.-u.-H.A.; Bilal, S.; Ayub, K. Doping and dedoping processes of polypyrrole: DFT study with hybrid functionals. J. Phys. Chem. C 2014, 118, 17819-17830. [CrossRef] 
37. Camurlu, P. Polypyrrole derivatives for electrochromic applications. RSC Adv. 2014, 4, 55832-55845. [CrossRef]

38. Ramanavičius, A.; Ramanavičienè, A.; Malinauskas, A. Electrochemical sensors based on conducting polymer-Polypyrrole. Electrochim. Acta 2006, 51, 6025-6037. [CrossRef]

39. Jain, S.; Mehata, M.S. Medicinal plant leaf extract and pure flavonoid mediated green synthesis of silver nanoparticles and their enhanced antibacterial property. Sci. Rep. 2017, 7, 15867. [CrossRef]

40. Maksymiuk, K. Chemical reactivity of polypyrrole and its relevance to polypyrrole based electrochemical sensors. Electroanalysis 2006, 18, 1537-1551. [CrossRef]

41. Cete, S.; Ozyurt, M.; Yildirim, E.; Akin, D. A novel biosensor with the use of polypyrrole-poly(sodium-4-styrenesulphonate) as a dopant in the determination of glucose. Chem. Pap. 2020, 74, 799-808. [CrossRef]

42. Ayenimo, J.G.; Adeloju, S.B. Amperometric detection of glucose in fruit juices with polypyrrole-based biosensor with an integrated permselective layer for exclusion of interferences. Food Chem. 2017, 229, 127-135. [CrossRef] [PubMed]

43. Loguercio, L.F.; Thesing, A.; Demingos, P.; de Albuquerque, C.D.; Rodrigues, R.S.; Brolo, A.G.; Santos, J.F. Efficient acetylcholinesterase immobilization for improved electrochemical performance in polypyrrole nanocomposite-based biosensors for carbaryl pesticide. Sens. Actuators B Chem. 2021, 339, 129875. [CrossRef]

44. De Morais, T.C.B.; Rodrigues, D.R.; de Carvalho Polari Souto, U.T.; Lemos, S.G. A simple voltammetric electronic tongue for the analysis of coffee adulterations. Food Chem. 2019, 273, 31-38. [CrossRef]

45. Podrażka, M.; Bączyńska, E.; Kundys, M.; Jeleń, P.S.; Nery, E.W. Electronic tongue-A tool for all tastes? Biosensors 2017, 8, 3. [CrossRef]

46. Sobrino-Gregorio, L.; Bataller, R.; Soto, J.; Escriche, I. Monitoring honey adulteration with sugar syrups using an automatic pulse voltammetric electronic tongue. Food Control 2018, 91, 254-260. [CrossRef]

47. Aliaño-González, M.J.; Ferreiro-González, M.; Barbero, G.F.; Ayuso, J.; Álvarez, J.A.; Palma, M.; Barroso, C.G. An electronic nose based method for the discrimination of weathered petroleum-derived products. Sensors 2018, 18, 2180. [CrossRef]

48. Ali, M.M.; Hashim, N.; Aziz, S.A.; Lasekan, O. Principles and recent advances in electronic nose for quality inspection of agricultural and food products. Trends Food Sci. Technol. 2020, 99, 1-10. [CrossRef]

49. Łagód, G.; Duda, S.M.; Majerek, D.; Szutt, A.; Dołhańczuk-Śródka, A. Application of electronic nose for evaluation of wastewater treatment process effects at full-scale WWTP. Processes 2019, 7, 251. [CrossRef]

50. Naveen, M.H.; Gurudatt, N.G.; Shim, Y.-B. Applications of conducting polymer composites to electrochemical sensors: A review. Appl. Mater. Today 2017, 9, 419-433. [CrossRef]

51. El Rhazi, M.; Majid, S.; Elbasri, M.; Salih, F.E.; Oularbi, L.; Lafdi, K. Recent progress in nanocomposites based on conducting polymer: Application as electrochemical sensors. Int. Nano Lett. 2018, 8, 79-99. [CrossRef]

52. John, A.; Benny, L.; Cherian, A.R.; Narahari, S.Y.; Varghese, A.; Hegde, G. Electrochemical sensors using conducting polymer/noble metal nanoparticle nanocomposites for the detection of various analytes: A review. J. Nanostruct. Chem. 2021, 11, 1-31. [CrossRef]

53. Kaur, G.; Kaur, A.; Kaur, H. Review on nanomaterials/conducting polymer based nanocomposites for the development of biosensors and electrochemical sensors. Polym. Technol. Mater. 2021, 60, 504-521. [CrossRef]

54. Dakshayini, B.; Reddy, K.R.; Mishra, A.; Shetti, N.P.; Malode, S.J.; Basu, S.; Naveen, S.; Raghu, A.V. Role of conducting polymer and metal oxide-based hybrids for applications in ampereometric sensors and biosensors. Microchem. J. 2019, 147, 7-24. [CrossRef]

55. Lu, L. Electrochemical sensor based on poly(3,4-ethylenedioxy-Thiophene) doped with transition metals for detecting rutin in buck wheat tea. Int. J. Electrochem. Sci. 2018, 2126-2135. [CrossRef]

56. Ibanez, J.G.; Rincón, M.E.; Gutierrez-Granados, S.; Chahma, M.; Jaramillo-Quintero, O.A.; Frontana-Uribe, B.A. Conducting polymers in the fields of energy, environmental remediation, and chemical-chiral sensors. Chem. Rev. 2018, 118, 4731-4816. [CrossRef]

57. Vasantha, V.; Chen, S.-M. Electrocatalysis and simultaneous detection of dopamine and ascorbic acid using poly(3,4ethylenedioxy)thiophene film modified electrodes. J. Electroanal. Chem. 2006, 592, 77-87. [CrossRef]

58. Revin, S.B.; John, S.A. Simultaneous determination of two important dopamine metabolites at physiological $\mathrm{pH}$ by voltammetry. Anal. Methods 2012, 4, 348-352. [CrossRef]

59. Revin, S.B.; John, A. Electrochemical sensor for neurotransmitters at physiological $\mathrm{pH}$ using a heterocyclic conducting polymer modified electrode. Analyst 2011, 137, 209-215. [CrossRef]

60. Yang, L.; Liu, S.; Zhang, Q.; Li, F. Simultaneous electrochemical determination of dopamine and ascorbic acid using AuNPs@polyaniline core-shell nanocomposites modified electrode. Talanta 2012, 89, 136-141. [CrossRef] [PubMed]

61. Roy, P.R.; Okajima, T.; Ohsaka, T. Simultaneous electroanalysis of dopamine and ascorbic acid using poly (N,N-dimethylaniline)modified electrodes. Bioelectrochemistry 2003, 59, 11-19. [CrossRef]

62. Wan, J.; Si, Y.; Li, C.; Zhang, K. Bisphenol A electrochemical sensor based on multi-walled carbon nanotubes/polythiophene/Pt nanocomposites modified electrode. Anal. Methods 2016, 8, 3333-3338. [CrossRef]

63. Ramachandran, T.; Dhayabaran, V.V. Utilization of a $\mathrm{MnO}_{2}$ / polythiophene/rGO nanocomposite modified glassy carbon electrode as an electrochemical sensor for methyl parathion. J. Mater. Sci. Mater. Electron. 2019, 30, 12315-12327. [CrossRef]

64. Saljooqi, A.; Shamspur, T.; Mostafavi, A. The electrochemical sensor based on graphene oxide nanosheets decorated by gold nanoparticles and polythiophene for nicotine sensing in biological samples and cigarette. J. Mater. Sci. Mater. Electron. 2020, 31, 5471-5477. [CrossRef] 
65. Hashemi, S.A.; Mousavi, S.M.; Bahrani, S.; Ramakrishna, S. Polythiophene silver bromide nanostructure as ultra-sensitive non-enzymatic electrochemical glucose biosensor. Eur. Polym. J. 2020, 138, 109959. [CrossRef]

66. GunaVathana, S.D.; Thivya, P.; Wilson, J.; Peter, A.C. Sensitive voltammetric sensor based on silver dendrites decorated polythiophene nanocomposite: Selective determination of L-Tryptophan. J. Mol. Struct. 2020, 1205, 127649. [CrossRef]

67. Song, Z.; Sheng, G.; Cui, Y.; Li, M.; Song, Z.; Ding, C.; Luo, X. Low fouling electrochemical sensing in complex biological media by using the ionic liquid-doped conducting polymer PEDOT: Application to voltammetric determination of dopamine. Microchim. Acta 2019, 186, 220. [CrossRef]

68. Tian, Q.; Xu, J.; Zuo, Y.; Li, Y.; Zhang, J.; Zhou, Y.; Duan, X.; Lu, L.; Jia, H.; Xu, Q.; et al. Three-dimensional PEDOT composite based electrochemical sensor for sensitive detection of chlorophenol. J. Electroanal. Chem. 2019, 837, 1-9. [CrossRef]

69. Li, M.; Wang, W.; Chen, Z.; Song, Z.; Luo, X. Electrochemical determination of paracetamol based on Au@graphene core-shell nanoparticles doped conducting polymer PEDOT nanocomposite. Sens. Actuators B Chem. 2018, 260, 778-785. [CrossRef]

70. Wu, L.-N.; Zhong, J.-P.; Waqas, M.; Jiang, Z.; Fan, Y.-J.; Sun, Y.; Li, J.; Chen, W. Controllable synthesis of six corner star-like $\mathrm{Cu}_{2} \mathrm{O} /$ PEDOT-MWCNT composites and their performance toward electrochemical glucose sensing. Electrochim. Acta 2019, 318, 837-846. [CrossRef]

71. Bottari, D.; Pigani, L.; Zanardi, C.; Terzi, F.; Paţurcă, S.V.; Grigorescu, S.D.; Matei, C.; Lete, C.; Lupu, S. Electrochemical sensing of caffeic acid using gold nanoparticles embedded in poly(3,4-ethylenedioxythiophene) layer by sinusoidal voltage procedure. Chemosensors 2019, 7, 65. [CrossRef]

72. García-Guzmán, J.J.; López-Iglesias, D.; Cubillana-Aguilera, L.; Lete, C.; Lupu, S.; Palacios-Santander, J.M.; Milla, D.B. Assessment of the polyphenol indices and antioxidant capacity for beers and wines using a tyrosinase-based biosensor prepared by sinusoidal current method. Sensors 2018, 19, 66. [CrossRef]

73. Ge, Y.; Jamal, R.; Zhang, R.; Zhang, W.; Yu, Z.; Yan, Y.; Liu, Y.; Abdiryim, T. Electrochemical synthesis of multilayered PEDOT/PEDOT-SH/Au nanocomposites for electrochemical sensing of nitrite. Microchim. Acta 2020, 187, 248. [CrossRef] [PubMed]

74. Motshakeri, M.; Phillips, A.R.J.; Travas-Sejdic, J.; Kilmartin, P.A. Electrochemical study of gold microelectrodes modified with PEDOT to quantify uric acid in milk samples. Electroanalysis 2020, 32, 2101-2111. [CrossRef]

75. Zhang, B.; El Jaouhari, A.; Wu, X.; Liu, W.; Zhu, J.; Liu, X. Synthesis and characterization of PEDOT-MC decorated AgNPs for voltammetric detection of rutin in real samples. J. Electroanal. Chem. 2020, 877, 114632. [CrossRef]

76. Lete, C.; Marin, M.; Anghel, E.M.; Preda, L.; Matei, C.; Lupu, S. Sinusoidal voltage electrodeposition of PEDOT-Prussian blue nanoparticles composite and its application to amperometric sensing of $\mathrm{H}_{2} \mathrm{O}_{2}$ in human blood. Mater. Sci. Eng. C 2019, 102, 661-669. [CrossRef]

77. Yassin, M.A.; Shrestha, B.K.; Ahmad, R.; Shrestha, S.; Park, C.H.; Kim, C.S. Exfoliated nanosheets of $\mathrm{Co}_{3} \mathrm{O}_{4}$ webbed with polyaniline nanofibers: A novel composite electrode material for enzymeless glucose sensing application. J. Ind. Eng. Chem. 2019, 73, 106-117. [CrossRef]

78. Saeb, E.; Asadpour-Zeynali, K. Facile synthesis of $\mathrm{TiO}_{2} @ P A N I @ A u$ nanocomposite as an electrochemical sensor for determination of hydrazine. Microchem. J. 2021, 160, 105603. [CrossRef]

79. Duan, C.; Zheng, J. Porous coralloid Polyaniline $/ \mathrm{SnO}_{2}$-based enzyme-free sensor for sensitive and selective detection of nitrite. Colloids Surf. A Physicochem. Eng. Asp. 2019, 567, 271-277. [CrossRef]

80. Fayemi, O.E.; Adekunle, A.; Swamy, B.; Ebenso, E.E. Electrochemical sensor for the detection of dopamine in real samples using polyaniline/ $\mathrm{NiO}, \mathrm{ZnO}$, and $\mathrm{Fe}_{3} \mathrm{O}_{4}$ nanocomposites on glassy carbon electrode. J. Electroanal. Chem. 2018, 818, 236-249. [CrossRef]

81. Mahmoudian, M.; Basirun, W.; Sookhakian, M.; Woi, P.M.; Zalnezhad, E.; Hazarkhani, H.; Alias, Y. Synthesis and characterization of $\alpha-\mathrm{Fe}_{2} \mathrm{O}_{3}$ / polyaniline nanotube composite as electrochemical sensor for uric acid detection. Adv. Powder Technol. 2019, 30, 384-392. [CrossRef]

82. Kailasaa, S.; Rani, B.G.; Reddy, M.S.B.; Jayarambabu, N.; Munindra, P.; Sharma, S.; Rao, K.V. NiO nanoparticles -decorated conductive polyaniline nanosheets for amperometric glucose biosensor. Mater. Chem. Phys. 2020, 242, 122524. [CrossRef]

83. Naghib, S.M.; Behzad, F.; Rahmanian, M.; Zare, Y.; Rhee, K.Y. A highly sensitive biosensor based on methacrylated graphene oxide-grafted polyaniline for ascorbic acid determination. Nanotechnol. Rev. 2020, 9, 760-767. [CrossRef]

84. Tavousi, A.; Ahmadi, E.; Mohammadi-Behzad, L.; Riahifar, V.; Maghemi, F. Sensitive electrochemical sensor using polypyrrolecoated $\mathrm{Fe}_{3} \mathrm{O}_{4}$ core-shell nanoparticles/multiwall carbon nanotubes modified graphite electrode for atorvastatin analysis. $\mathrm{Mi}$ crochem. J. 2020, 158, 105159. [CrossRef]

85. Kannan, A.; Radhakrishnan, S. Fabrication of an electrochemical sensor based on gold nanoparticles functionalized polypyrrole nanotubes for the highly sensitive detection of 1-dopa. Mater. Today Commun. 2020, 25, 101330. [CrossRef]

86. Adeosun, W.A.; Asiri, A.M.; Marwani, H.M.; Rahman, M. Enzymeless electrocatalytic detection of uric acid using polydopamine/polypyrrole copolymeric film. ChemistrySelect 2020, 5, 156-164. [CrossRef]

87. Arabali, V.; Malekmohammadi, S.; Karimi, F. Surface amplification of pencil graphite electrode using CuO nanoparticle/polypyrrole nanocomposite; a powerful electrochemical strategy for determination of tramadol. Microchem. J. 2020, 158, 105179. [CrossRef]

88. Mengarda, P.; Dias, F.A.L.; Peixoto, J.V.; Osiecki, R.; Bergamini, M.F.; Marcolino-Junior, L.H. Determination of lactate levels in biological fluids using a disposable ion-selective potentiometric sensor based on polypyrrole films. Sens. Actuators B Chem. 2019, 296, 126663. [CrossRef] 
89. Ma, J.; Zheng, J. Voltammetric determination of hydrogen peroxide using AuCu nanoparticles attached on polypyrrole-modified 2D metal-organic framework nanosheets. Microchim. Acta 2020, 187, 389. [CrossRef]

90. Robak, J.; Burnat, B.; Leniart, A.; Kisielewska, A.; Brycht, M.; Skrzypek, S. The effect of carbon material on the electroanalytical determination of 4-chloro-3-methylphenol using the sol-gel derived carbon ceramic electrodes. Sens. Actuators B Chem. 2016, 236, 318-325. [CrossRef]

91. Darmokoesoemo, H.; Widayanti, N.; Khasanah, M.; Kusuma, H. Analysis of uric acid using carbon paste electrodes modified by molecularly imprinted polymer as potentiometry sensor. Rasayan J. Chem. 2017, 10, 54-58. [CrossRef]

92. Abrishamkar, M.; Kiani, F. Electrocatalytic oxidation of hydrogen peroxide on the surface of nano zeolite modified carbon paste electrode. Int. J. Hydrogen Energy 2017, 42, 23826-23831. [CrossRef]

93. Li, D.; Liu, M.; Zhan, Y.; Su, Q.; Zhang, Y.; Zhang, D. Electrodeposited poly(3,4-ethylenedioxythiophene) doped with graphene oxide for the simultaneous voltammetric determination of ascorbic acid, dopamine and uric acid. Microchim. Acta 2020, 187, 94. [CrossRef]

94. Huang, Y.; Bai, S.; Huang, J.; Ma, Y.; Zeng, Q.; Wang, M.; Wang, L. Simultaneous detection of nitrophenol isomers using an easy-to-fabricate thiophene-based microporous polymer film modified electrode. Microchem. J. 2020, 153, 104465. [CrossRef]

95. Prathap, M.A.; Srivastava, R. Tailoring properties of polyaniline for simultaneous determination of a quaternary mixture of ascorbic acid, dopamine, uric acid, and tryptophan. Sens. Actuators B Chem. 2013, 177, 239-250. [CrossRef]

96. Prathap, M.A.; Satpati, B.; Srivastava, R. Facile preparation of polyaniline $/ \mathrm{MnO}_{2}$ nanofibers and its electrochemical application in the simultaneous determination of catechol, hydroquinone, and resorcinol. Sens. Actuators B Chem. 2013, 186, 67-77. [CrossRef]

97. Promphet, N.; Rattanarat, P.; Rangkupan, R.; Chailapakul, O.; Rodthongkum, N. An electrochemical sensor based on graphene/polyaniline/polystyrene nanoporous fibers modified electrode for simultaneous determination of lead and cadmium. Sens. Actuators B Chem. 2015, 207, 526-534. [CrossRef]

98. Ghanbari, K.; Moloudi, M. Flower-like ZnO decorated polyaniline/reduced graphene oxide nanocomposites for simultaneous determination of dopamine and uric acid. Anal. Biochem. 2016, 512, 91-102. [CrossRef]

99. Tan, C.; Zhao, J.; Sun, P.; Zheng, W.; Cui, G. Gold nanoparticle decorated polypyrrole/graphene oxide nanosheets as a modified electrode for simultaneous determination of ascorbic acid, dopamine and uric acid. New J. Chem. 2020, 44, 4916-4926. [CrossRef]

100. Wang, M.; Cui, M.; Liu, W.; Liu, X. Highly dispersed conductive polypyrrole hydrogels as sensitive sensor for simultaneous determination of ascorbic acid, dopamine and uric acid. J. Electroanal. Chem. 2019, 832, 174-181. [CrossRef]

101. Gautam, V.; Srivastava, A.; Singh, K.P.; Yadav, V.L. Preparation and characterization of polyaniline, multiwall carbon nanotubes, and starch bionanocomposite material for potential bioanalytical applications. Polym. Compos. 2017, 38, 496-506. [CrossRef]

102. Gautam, V.; Singh, K.P.; Yadav, V.L. Polyaniline/MWCNTs/starch modified carbon paste electrode for non-enzymatic detection of cholesterol: Application to real sample (cow milk). Anal. Bioanal. Chem. 2018, 410, 2173-2181. [CrossRef]

103. López-Iglesias, D.; García-Guzmán, J.J.; Bellido-Milla, D.; Naranjo-Rodríguez, I.; Palacios-Santander, J.M.; Cubillana-Aguilera, L. The sonogel-carbon-PEDOT Material: An innovative bulk material for sensor devices. J. Electrochem. Soc. 2018, 165, B906-B915. [CrossRef]

104. López-Iglesias, D.; García-Guzmán, J.J.; Zanardi, C.; Palacios-Santander, J.M.; Cubillana-Aguilera, L.; Pigani, L. Fast electroanalytical determination of Cannabidiol and Cannabinol in aqueous solution using Sonogel-carbon-PEDOT devices. J. Electroanal. Chem. 2020, 878, 114591. [CrossRef]

105. Ha, D.; Sun, Q.; Su, K.; Wan, H.; Li, H.; Xu, N.; Sun, F.; Zhuang, L.; Hu, N.; Wang, P. Recent achievements in electronic tongue and bioelectronic tongue as taste sensors. Sens. Actuators B Chem. 2015, 207, 1136-1146. [CrossRef]

106. Del Valle, M. Electronic tongues employing electrochemical sensors. Electroanalysis 2010, 22, 1539-1555. [CrossRef]

107. Pérez-Ràfols, C.; Serrano, N.; Ariño, C.; Esteban, M.; Díaz-Cruz, J.M. Voltammetric electronic tongues in food analysis. Sensors 2019, 19, 4261. [CrossRef]

108. Kirsanov, D.; Correa, D.S.; Gaal, G.; Riul, A.; Braunger, M.L.; Shimizu, F.M.; Oliveira, O.N.; Liang, T.; Wan, H.; Wang, P.; et al. Electronic tongues for inedible media. Sensors 2019, 19, 5113. [CrossRef]

109. Riul, A.; Malmegrim, R.; Fonseca, F.; Mattoso, L. An artificial taste sensor based on conducting polymers. Biosens. Bioelectron. 2003, 18, 1365-1369. [CrossRef]

110. Riul, A., Jr.; dos Santos, D.S., Jr.; Wohnrath, K.; Di Tommazo, R.; Carvalho, A.C.P.L.F.; Fonseca, F.J.; Oliveira, O.N., Jr.; Taylor, D.M.; Mattoso, L.H.C. Artificial taste sensor: Efficient combination of sensors made from langmuir-blodgett films of conducting polymers and a ruthenium complex and self-assembled films of an azobenzene-containing polymer. Langmuir 2002, 18, 239-245. [CrossRef]

111. Riul, A.; Soto, A.G.; Mello, S.; Bone, S.; Taylor, D.; Mattoso, L. An electronic tongue using polypyrrole and polyaniline. Synth. Met. 2003, 132, 109-116. [CrossRef]

112. Arrieta, A.; Apetrei, C.; Rodriguez-Mendez, M.L.; de Saja, J. Voltammetric sensor array based on conducting polymer-modified electrodes for the discrimination of liquids. Electrochim. Acta 2004, 49, 4543-4551. [CrossRef]

113. Lvova, L.; Legin, A.; Vlasov, Y.; Cha, G.S.; Nam, H. Multicomponent analysis of Korean green tea by means of disposable all-solid-state potentiometric electronic tongue microsystem. Sens. Actuators B Chem. 2003, 95, 391-399. [CrossRef]

114. Pigani, L.; Simone, G.V.; Foca, G.; Ulrici, A.; Masino, F.; Aguilera, L.C.; Calvini, R.; Seeber, R. Prediction of parameters related to grape ripening by multivariate calibration of voltammetric signals acquired by an electronic tongue. Talanta 2018, 178, 178-187. [CrossRef] [PubMed] 
115. Pigani, L.; Culetu, A.; Ulrici, A.; Foca, G.; Vignali, M.; Seeber, R. Pedot modified electrodes in amperometric sensing for analysis of red wine samples. Food Chem. 2011, 129, 226-233. [CrossRef]

116. Martina, V.; Ionescu, K.; Pigani, L.; Terzi, F.; Ulrici, A.; Zanardi, C.; Seeber, R. Development of an electronic tongue based on a PEDOT-modified voltammetric sensor. Anal. Bioanal. Chem. 2007, 387, 2101-2110. [CrossRef]

117. Scagion, V.P.; Mercante, L.; Sakamoto, K.Y.; Oliveira, J.; Fonseca, F.J.; Mattoso, L.H.C.; Ferreira, M.D.; Correa, D.S. An electronic tongue based on conducting electrospun nanofibers for detecting tetracycline in milk samples. RSC Adv. 2016, 6, 103740-103746. [CrossRef]

118. Yu, Y.; Joshi, P.C.; Wu, J.; Hu, A. Laser-Induced carbon-based smart flexible sensor array for multiflavors detection. ACS Appl. Mater. Interfaces 2018, 10, 34005-34012. [CrossRef]

119. Garcia-Hernandez, C.; Salvo-Comino, C.; Martin-Pedrosa, F.; Garcia-Cabezon, C.; Rodriguez-Mendez, M. Analysis of red wines using an electronic tongue and infrared spectroscopy. Correlations with phenolic content and color parameters. LWT 2020, 118, 108785. [CrossRef]

120. Geană, E.-I.; Ciucure, C.T.; Artem, V.; Apetrei, C. Wine varietal discrimination and classification using a voltammetric sensor array based on modified screen-printed electrodes in conjunction with chemometric analysis. Microchem. J. 2020, $159,105451$. [CrossRef]

121. Parra, V.; Arrieta, Á.A.; Escudero, J.F.; Rodríguez-Méndez, M.L.; De Saja, J.A. Electronic tongue based on chemically modified electrodes and voltammetry for the detection of adulterations in wines. Sens. Actuators B Chem. 2006, 118, 448-453. [CrossRef]

122. Apetrei, I.M.; Apetrei, C. Application of voltammetric e-tongue for the detection of ammonia and putrescine in beef products. Sens. Actuators B Chem. 2016, 234, 371-379. [CrossRef]

123. Arrieta, Á.A.; Rodriguez-Mendez, M.L.; de Saja, J.A.; Blanco, C.A.; Nimubona, D. Prediction of bitterness and alcoholic strength in beer using an electronic tongue. Food Chem. 2010, 123, 642-646. [CrossRef]

124. Apetrei, C. Novel method based on polypyrrole-modified sensors and emulsions for the evaluation of bitterness in extra virgin olive oils. Food Res. Int. 2012, 48, 673-680. [CrossRef]

125. Geană, E.-I.; Artem, V.; Apetrei, C. Discrimination and classification of wines based on polypyrrole modified screen-printed carbon electrodes coupled with multivariate data analysis. J. Food Compos. Anal. 2021, 96, 103704. [CrossRef]

126. Gutiérrez, J.M.; Moreno-Barón, L.; Pividori, M.I.; Alegret, S.; del Valle, M. A voltammetric electronic tongue made of modified epoxy-graphite electrodes for the qualitative analysis of wine. Microchim. Acta 2010, 169, 261-268. [CrossRef]

127. Cetó, X.; Capdevila, J.; Puig-Pujol, A.; Del Valle, M. Cava wine authentication employing a voltammetric electronic tongue. Electroanalysis 2014, 26, 1504-1512. [CrossRef]

128. Cetó, X.; Gutiérrez, J.M.; Gutiérrez, M.; Céspedes, F.; Capdevila, J.; Mínguez, S.; Jimenez-Jorquera, C.; Del Valle, M. Determination of total polyphenol index in wines employing a voltammetric electronic tongue. Anal. Chim. Acta 2012, 732, 172-179. [CrossRef]

129. Wei, Z.; Yang, Y.; Xiao, X.; Zhang, W.; Wang, J. Fabrication of conducting polymer/noble metal nanocomposite modified electrodes for glucose, ascorbic acid and tyrosine detection and its application to identify the marked ages of rice wines. Sens. Actuators $B$ Chem. 2018, 255, 895-906. [CrossRef]

130. Wang, J.; Zhu, L.; Zhang, W.; Wei, Z. Application of the voltammetric electronic tongue based on nanocomposite modified electrodes for identifying rice wines of different geographical origins. Anal. Chim. Acta 2019, 1050, 60-70. [CrossRef]

131. Pioggia, G.; Di Francesco, F.; Marchetti, A.; Ferro, M.; Ahluwalia, A. A composite sensor array impedentiometric electronic tongue: Part I. Characterization. Biosens. Bioelectron. 2007, 22, 2618-2623. [CrossRef] [PubMed]

132. Pioggia, G.; Di Francesco, F.; Marchetti, A.; Ferro, M.; Leardi, R.; Ahluwalia, A. A composite sensor array impedentiometric electronic tongue: Part II. Discrimination of basic tastes. Biosens. Bioelectron. 2007, 22, 2624-2628. [CrossRef]

133. Braga, G.S.; Paterno, L.G.; Fonseca, F.J. Performance of an electronic tongue during monitoring 2-methylisoborneol and geosmin in water samples. Sens. Actuators B Chem. 2012, 171-172, 181-189. [CrossRef]

134. Carvalho, E.R.; Lopes, W.T.; Silva, D. Evaluation of tap water based on sensor array and conducting nanostructured polymers. Nanotechnol. J. Water Environ. Nanotechnol 2016, 1, 116-123. [CrossRef]

135. Facure, M.H.M.; Mercante, L.; Mattoso, L.H.; Correa, D.S. Detection of trace levels of organophosphate pesticides using an electronic tongue based on graphene hybrid nanocomposites. Talanta 2017, 167, 59-66. [CrossRef]

136. Oliveira, J.E.; Scagion, V.P.; Grassi, V.; Correa, D.; Mattoso, L.H. Modification of electrospun nylon nanofibers using layer-by-layer films for application in flow injection electronic tongue: Detection of paraoxon pesticide in corn crop. Sens. Actuators B Chem. 2012, 171-172, 249-255. [CrossRef]

137. Apetrei, I.M.; Apetrei, C. Amperometric biosensor based on polypyrrole and tyrosinase for the detection of tyramine in food samples. Sens. Actuators B Chem. 2013, 178, 40-46. [CrossRef]

138. Kochana, J.; Hnida, K.; Sulka, G.; Knihnicki, P.; Kozak, J.; Gilowska, A. Application of polypyrrole nanowires for the development of a tyrosinase biosensor. Chem. Pap. 2015, 69, 1130-1135. [CrossRef]

139. Garcia-Hernandez, C.; Garcia-Cabezon, C.; Martin-Pedrosa, F.; Rodriguez-Mendez, M. Analysis of musts and wines by means of a bio-electronic tongue based on tyrosinase and glucose oxidase using polypyrrole/gold nanoparticles as the electron mediator. Food Chem. 2019, 289, 751-756. [CrossRef]

140. Mao, H.; Liu, X.; Chao, D.; Cui, L.; Li, Y.; Zhang, W.; Wang, C. Preparation of unique PEDOT nanorods with a couple of cuspate tips by reverse interfacial polymerization and their electrocatalytic application to detect nitrite. J. Mater. Chem. 2010, 20, 10277-10284. [CrossRef] 
141. Zhang, K.; Xu, J.; Zhu, X.; Lu, L.; Duan, X.; Hu, D.; Dong, L.; Sun, H.; Gao, Y.; Wu, Y. Poly(3,4-ethylenedioxythiophene) nanorods grown on graphene oxide sheets as electrochemical sensing platform for rutin. J. Electroanal. Chem. 2015, 739, 66-72. [CrossRef]

142. Wiziack, N.K.L.; Paterno, L.G.; Fonseca, F.J.; Mattoso, L.H.C. Effect of film thickness and different electrode geometries on the performance of chemical sensors made of nanostructured conducting polymer films. Sens. Actuators B Chem. 2007, 122, 484-492. [CrossRef]

143. Arshak, K.; Moore, E.; Lyons, G.; Harris, J.; Clifford, S. A review of gas sensors employed in electronic nose applications. Sens. Rev. 2004, 24, 181-198. [CrossRef]

144. Pirsa, S. Chemiresistive gas sensors based on conducting polymers. In Materials Science and Engineering: Concepts, Methodologies, Tools, and Applications; IGI Global: Hershey, PA, USA, 2017; pp. 543-574.

145. Lakard, B.; Carquigny, S.; Segut, O.; Patois, T.; Lakard, S. Gas sensors based on electrodeposited polymers. Metals 2015, 5, 1371-1386. [CrossRef]

146. Park, S.J.; Park, C.S.; Yoon, H. Chemo-Electrical gas sensors based on conducting polymer hybrids. Polymers 2017, 9, 155. [CrossRef]

147. Wu, W.; Wang, B.; Segev-Bar, M.; Dou, W.; Niu, F.; Horev, Y.D.; Deng, Y.; Plotkin, M.; Huynh, T.-P.; Jeries, R.; et al. Free-Standing and eco-friendly polyaniline thin films for multifunctional sensing of physical and chemical stimuli. Adv. Funct. Mater. 2017, 27, 27. [CrossRef]

148. Zhang, T.; Qi, H.; Liao, Z.; Horev, Y.D.; Panes-Ruiz, L.A.; Petkov, P.S.; Zhang, Z.; Shivhare, R.; Zhang, P.; Liu, K.; et al. Engineering crystalline quasi-two-dimensional polyaniline thin film with enhanced electrical and chemiresistive sensing performances. Nat. Commun. 2019, 10, 4225. [CrossRef]

149. Duc, C.; Boukhenane, M.-L.; Wojkiewicz, J.-L.; Redon, N. Hydrogen sulfide detection by sensors based on conductive polymers: A review. Front. Mater. 2020, 7, 215. [CrossRef]

150. Mikhaylov, S.; Ogurtsov, N.A.; Redon, N.; Coddeville, P.; Wojkiewicz, J.-L.; Pud, A.A. The PANI-DBSA content and dispersing solvent as influencing parameters in sensing performances of $\mathrm{TiO}_{2}$ /PANI-DBSA hybrid nanocomposites to ammonia. RSC Adv. 2016, 6, 82625-82634. [CrossRef]

151. Hong, K.H.; Oh, K.W.; Kang, T.J. Polyaniline-nylon 6 composite fabric for ammonia gas sensor. J. Appl. Polym. Sci. 2004, 92, 37-42. [CrossRef]

152. Hu, H.; Trejo, M.; Nicho, M.; Saniger, J.; García-Valenzuela, A. Adsorption kinetics of optochemical $\mathrm{NH}_{3}$ gas sensing with semiconductor polyaniline films. Sens. Actuators B Chem. 2002, 82, 14-23. [CrossRef]

153. Xu, M.; Zhang, J.; Wang, S.; Guo, X.; Xia, H.; Wang, Y.; Zhang, S.; Huang, W.; Wu, S. Gas sensing properties of SnO 2 hollow spheres/polythiophene inorganic-organic hybrids. Sens. Actuators B Chem. 2010, 146, 8-13. [CrossRef]

154. Zhang, Y.; Bunes, B.R.; Wu, N.; Ansari, A.; Rajabali, S.; Zang, L. Sensing methamphetamine with chemiresistive sensors based on polythiophene-blended single-walled carbon nanotubes. Sens. Actuators B Chem. 2018, 255, 1814-1818. [CrossRef]

155. Lv, D.; Chen, W.; Shen, W.; Peng, M.; Zhang, X.; Wang, R.; Xu, L.; Xu, W.; Song, W.; Tan, R. Enhanced flexible room temperature ammonia sensor based on PEDOT: PSS thin film with $\mathrm{FeCl}_{3}$ additives prepared by inkjet printing. Sens. Actuators B Chem. 2019, 298, 126890. [CrossRef]

156. Ram, J.; Singh, R.G.; Singh, F.; Kumar, V.; Chauhan, V.; Gupta, R.; Kumar, U.; Yadav, B.C.; Kumar, R. Development of WO 3 -PEDOT: PSS hybrid nanocomposites based devices for liquefied petroleum gas (LPG) sensor. J. Mater. Sci. Mater. Electron. 2019, 30, 13593-13603. [CrossRef]

157. Yang, P.; Lv, D.; Shen, W.; Wu, T.; Yang, Y.; Zhao, Y.; Tan, R.; Song, W. Porous flexible polyaniline/polyvinylidene fluoride composite film for trace-level $\mathrm{NH}_{3}$ detection at room temperature. Mater. Lett. 2020, 271, 127798. [CrossRef]

158. Xu, H.; Ju, D.; Li, W.; Gong, H.; Zhang, J.; Wang, J.; Cao, B. Low-working-temperature, fast-response-speed $\mathrm{NO}_{2}$ sensor with nanoporous-SnO 2 /polyaniline double-layered film. Sens. Actuators B Chem. 2016, 224, 654-660. [CrossRef]

159. Zhang, D.; Wu, Z.; Zong, X. Flexible and highly sensitive $\mathrm{H}_{2} \mathrm{~S}$ gas sensor based on in-situ polymerized $\mathrm{SnO} / 2 / \mathrm{rGO} / \mathrm{PANI}$ ternary nanocomposite with application in halitosis diagnosis. Sens. Actuators B Chem. 2019, 289, 32-41. [CrossRef]

160. Kotresh, S.; Ravikiran, Y.T.; Vijayakumari, S.C.; Thomas, S. Interfacial p-n heterojunction of polyaniline-nickel ferrite nanocomposite as room temperature liquefied petroleum gas sensor. Compos. Interfaces 2017, 24, 549-561. [CrossRef]

161. Tang, X.; Raskin, J.-P.; Kryvutsa, N.; Hermans, S.; Slobodian, O.; Nazarov, A.N.; Debliquy, M. An ammonia sensor composed of polypyrrole synthesized on reduced graphene oxide by electropolymerization. Sens. Actuators B Chem. 2020, $305,127423$. [CrossRef]

162. Navale, S.; Mane, A.; Chougule, M.; Sakhare, R.; Nalage, S.; Patil, V. Highly selective and sensitive room temperature $\mathrm{NO}_{2}$ gas sensor based on polypyrrole thin films. Synth. Met. 2014, 189, 94-99. [CrossRef]

163. Adhikari, A.; Tiwary, P.; Rana, D.; Halder, A.; Nath, J.; Basu, A.; Ghoshal, D.; Kar, P.; Chakraborty, A.K.; Chattopadhyay, D. Na-cholate micelle mediated synthesis of polypyrrole nanoribbons for ethanol sensing. J. Environ. Chem. Eng. 2020, 8, 104249. [CrossRef]

164. Adhikari, A.; Kar, P.; Rana, D.; De, S.; Nath, J.; Dutta, K.; Chattopadhyay, D. Synthesis of sodium cholate mediated rod-like polypyrrole-silver nanocomposite for selective sensing of acetone vapor. Nano Struct. Nano Objects 2020, 21, 100419. [CrossRef]

165. Park, S.J.; Kwon, O.S.; Jang, J. A high-performance hydrogen gas sensor using ultrathin polypyrrole-coated CNT nanohybrids. Chem. Commun. 2013, 49, 4673. [CrossRef] 
166. Deng, Y.; Sun, J.; Jin, H.; Khatib, M.; Li, X.; Wei, Z.; Wang, F.; Horev, Y.D.; Wu, W.; Haick, H. Chemically modified polyaniline for the detection of volatile biomarkers of minimal sensitivity to humidity and bending. Adv. Heal. Mater. 2018, 7, e1800232. [CrossRef]

167. Behera, B.; Joshi, R.; Vishnu, G.K.A.; Bhalerao, S.; Pandya, H.J. Electronic nose: A non-invasive technology for breath analysis of diabetes and lung cancer patients. J. Breath Res. 2019, 13, 024001. [CrossRef]

168. Wilson, A.D. Application of electronic-nose technologies and voc-biomarkers for the noninvasive early diagnosis of gastrointestinal diseases. Sensors 2018, 18, 2613. [CrossRef]

169. Liu, B.; Huang, Y.; Kam, K.W.; Cheung, W.-F.; Zhao, N.; Zheng, B. Functionalized graphene-based chemiresistive electronic nose for discrimination of disease-related volatile organic compounds. Biosens. Bioelectron. X 2019, 1, 100016. [CrossRef]

170. Nategh, N.A.; Dalvand, M.J.; Anvar, A. Detection of toxic and non-toxic sweet cherries at different degrees of maturity using an electronic nose. J. Food Meas. Charact. 2021, 15, 1213-1224. [CrossRef]

171. Hatfield, J.; Neaves, P.; Hicks, P.; Persaud, K.; Travers, P. Towards an integrated electronic nose using conducting polymer sensors. Sens. Actuators B Chem. 1994, 18, 221-228. [CrossRef]

172. Stella, R.; Barisci, J.N.; Serra, G.; Wallace, G.; De Rossi, D. Characterisation of olive oil by an electronic nose based on conducting polymer sensors. Sens. Actuators B Chem. 2000, 63, 1-9. [CrossRef]

173. Barisci, J.N.; Wallace, G.G.; Andrews, M.K.; Partridge, A.C.; Harris, P.D. Conducting polymer sensors for monitoring aromatic hydrocarbons using an electronic nose. Sens. Actuators B Chem. 2002, 84, 252-257. [CrossRef]

174. Sen, T.; Mishra, S.; Shimpi, N.G. Synthesis and sensing applications of polyaniline nanocomposites: A review. RSC Adv. 2016, 6, 42196-42222. [CrossRef]

175. Pandey, S. Highly sensitive and selective chemiresistor gas/vapor sensors based on polyaniline nanocomposite: A comprehensive review. J. Sci. Adv. Mater. Devices 2016, 1, 431-453. [CrossRef]

176. Liu, H.; Wu, Y.; Chen, S.; Liu, S.; Wang, P.; Xue, F.; Liu, L. A flexible and multifunctional electronic nose using polyaniline/cotton fibrous membrane with a hierarchical structure. Mater. Lett. 2018, 233, 324-327. [CrossRef]

177. Tiggemann, L.; Ballen, S.C.; Bocalon, C.M.; Graboski, A.M.; Manzoli, A.; Steffens, J.; Valduga, E.; Steffens, C. Electronic nose system based on polyaniline films sensor array with different dopants for discrimination of artificial aromas. Innov. Food Sci. Emerg. Technol. 2017, 43, 112-116. [CrossRef]

178. Graboski, A.M.; Ballen, S.C.; Galvagni, E.; Lazzari, T.; Manzoli, A.; Shimizu, F.M.; Steffens, J.; Steffens, C. Aroma detection using a gas sensor array with different polyaniline films. Anal. Methods 2019, 11, 654-660. [CrossRef]

179. Manzoli, A.; Steffens, C.; Paschoalin, R.T.; Graboski, A.M.; Brandão, H.; de Carvalho, B.C.; Bellini, J.L.; Herrmann, P.S.D.P. Volatile compounds monitoring as indicative of female cattle fertile period using electronic nose. Sens. Actuators B Chem. 2019, 282, 609-616. [CrossRef]

180. Manzoli, A.; Steffens, C.; Paschoalin, R.T.; Correa, A.A.; Alves, W.F.; Leite, F.L.; Herrmann, P.S.P. Low-Cost gas sensors produced by the graphite line-patterning technique applied to monitoring banana ripeness. Sensors 2011, 11, 6425-6434. [CrossRef] [PubMed]

181. Ballen, S.C.; Graboski, A.M.; Manzoli, A.; Steffens, J.; Steffens, C. Monitoring aroma release in gummy candies during the storage using electronic nose. Food Anal. Methods 2019, 13, 3-12. [CrossRef]

182. Le Maout, P.; Wojkiewicz, J.-L.; Redon, N.; Lahuec, C.; Seguin, F.; Dupont, L.; Mikhaylov, S.; Noskov, Y.; Ogurtsov, N.; Pud, A. Polyaniline nanocomposites based sensor array for breath ammonia analysis. Portable e-nose approach to non-invasive diagnosis of chronic kidney disease. Sens. Actuators B Chem. 2018, 274, 616-626. [CrossRef]

183. Le Maout, P.; Laquintinie, P.; Lahuec, C.; Seguin, F.; Wojkiewicz, J.-L.; Redon, N.; Dupont, L. A Low Cost, Handheld E-Nose for Renal Diseases Early Diagnosis. In Proceedings of the 2018 40th Annual International Conference of the IEEE Engineering in Medicine and Biology Society (EMBC), Honolulu, HI, USA, 18-21 July 2018; Volume 2018, pp. 2817-2820.

184. Graboski, A.M.; Zakrzevski, C.A.; Shimizu, F.M.; Paschoalin, R.T.; Soares, A.C.; Steffens, J.; Paroul, N.; Steffens, C. Electronic nose based on carbon nanocomposite sensors for clove essential oil detection. ACS Sens. 2020, 5, 1814-1821. [CrossRef]

185. Tung, T.T.; Castro, M.; Feller, J.-F.; Kim, T.Y.; Suh, K.S. Hybrid film of chemically modified graphene and vapor-phase-polymerized PEDOT for electronic nose applications. Org. Electron. 2013, 14, 2789-2794. [CrossRef]

186. Hamilton, S.; Hepher, M.; Sommerville, J. Polypyrrole materials for detection and discrimination of volatile organic compounds. Sens. Actuators B Chem. 2005, 107, 424-432. [CrossRef]

187. Alizadeh, N.; Babaei, M.; Alizadeh, M.S.; Mani-Varnosfaderani, A. Simultaneous Analysis of Aliphatic Alcohols Mixtures Using an Electronic Nose Based on Nano/Microstructured Conducting Polypyrrole Film Prepared by Catalytic Electropolymerization on $\mathrm{Cu} / \mathrm{Au}$ Interdigital Electrodes Using Multivariate Calibration. IEEE Sens. J. 2015, 16, 418-425. [CrossRef]

188. Cavallari, M.R.; Izquierdo, J.E.E.; Braga, G.S.; Dirani, E.A.T.; Pereira-Da-Silva, M.A.; Rodríguez, E.F.G.; Fonseca, F.J. Enhanced sensitivity of gas sensor based on poly(3-hexylthiophene) thin-film transistors for disease diagnosis and environment monitoring Sensors 2015, 15, 9592-9609. [CrossRef] [PubMed]

189. Esteves, C.H.A.; Iglesias, B.A.; Ogawa, T.; Araki, K.; Hoehne, L.; Gruber, J. Identification of tobacco types and cigarette brands using an electronic nose based on conductive polymer/porphyrin composite sensors. ACS Omega 2018, 3, 6476-6482. [CrossRef]

190. Abbas, N.K.; Ibrahim, I.M.; Saleh, M.A. Characteristics of MEH-PPV/Si and MEH-PPV/PS heterojunctions as $\mathrm{NO}_{2}$ Gas sensors. Silicon 2018, 10, 1345-1350. [CrossRef]

191. Jafari, A.; Amini, A. Lactic acid gas sensor based on polypyrrole thin film. Mater. Lett. 2019, 236, 175-178. [CrossRef] 
192. Rañola, R.A.G.; Santiago, K.S.; Sevilla, F.B. Chemiresistor gas sensor array based on conducting polymers for the discrimination of virgin coconut oil. Appl. Mech. Mater. 2015, 789-790, 554-559. [CrossRef]

193. Gruber, J.; Nascimento, H.M.; Yamauchi, E.Y.; Li, R.W.; Esteves, C.H.; Rehder, G.; Gaylarde, C.C.; Shirakawa, M.A. A conductive polymer based electronic nose for early detection of Penicillium digitatum in post-harvest oranges. Mater. Sci. Eng. C 2013, 33, 2766-2769. [CrossRef] [PubMed]

194. Castro, M.; Kumar, B.; Feller, J.; Haddi, Z.; Amari, A.; Bouchikhi, B. Novel e-nose for the discrimination of volatile organic biomarkers with an array of carbon nanotubes (CNT) conductive polymer nanocomposites (CPC) sensors. Sens. Actuators B Chem. 2011, 159, 213-219. [CrossRef]

195. Molla-Abbasi, P.; Shabanian, M. A bulky aromatic functional polyimide composite as a sensitive layer for the detection of organic compound biomarkers. Iran. Polym. J. 2019, 28, 203-211. [CrossRef]

196. Jiménez-Cadena, G.; Riu, J.; Rius, F.X. Gas sensors based on nanostructured materials. Analyst 2007, 132, 1083-1099. [CrossRef] [PubMed]

197. Yang, Y.; Li, S.; Yang, W.; Yuan, W.; Xu, J.; Jiang, Y. In Situ polymerization deposition of porous conducting polymer on reduced graphene oxide for gas sensor. ACS Appl. Mater. Interfaces 2014, 6, 13807-13814. [CrossRef]

198. Kwon, O.S.; Hong, J.-Y.; Park, S.J.; Jang, Y.; Jang, J. Resistive gas sensors based on precisely size-controlled polypyrrole nanoparticles: Effects of particle size and deposition method. J. Phys. Chem. C 2010, 114, 18874-18879. [CrossRef]

199. Ma, Z.; Chen, P.; Cheng, W.; Yan, K.; Pan, L.; Shi, Y.; Yu, G. Highly sensitive, printable nanostructured conductive polymer wireless sensor for food spoilage detection. Nano Lett. 2018, 18, 4570-4575. [CrossRef]

200. Bertoni, C.; Naclerio, P.; Viviani, E.; Zilio, S.D.; Carrato, S.; Fraleoni-Morgera, A. Nanostructured p3ht as a promising sensing element for real-time, dynamic detection of gaseous acetone. Sensors 2019, 19, 1296. [CrossRef]

201. Di Rosa, A.R.; Marino, A.M.F.; Leone, F.; Corpina, G.G.; Giunta, R.P.; Chiofalo, V. Characterization of sicilian honeys pollen profiles using a commercial e-tongue and melissopalynological analysis for rapid screening: A pilot study. Sensors 2018, 18, 4065 . [CrossRef]

202. Major, N.; Marković, K.; Krpan, M.; Šarić, G.; Hruškar, M.; Vahčić, N. Rapid honey characterization and botanical classification by an electronic tongue. Talanta 2011, 85, 569-574. [CrossRef]

203. Zhang, X.; Zhang, Y.; Meng, Q.; Li, N.; Ren, L. Evaluation of beef by electronic tongue system TS-5000Z: Flavor assessment, recognition and chemical compositions according to its correlation with flavor. PLoS ONE 2015, 10, e0137807. [CrossRef] [PubMed]

204. Woertz, K.; Tissen, C.; Kleinebudde, P.; Breitkreutz, J. A comparative study on two electronic tongues for pharmaceutical formulation development. J. Pharm. Biomed. Anal. 2011, 55, 272-281. [CrossRef] [PubMed]

205. Liu, M.; Wang, J.; Li, D.; Wang, M. Electronic tongue coupled with physicochemical analysis for the recognition of orange beverages. J. Food Qual. 2012, 35, 429-441. [CrossRef]

206. Pein, M.; Kirsanov, D.; Ciosek, P.; Del Valle, M.; Yaroshenko, I.; Wesoły, M.; Zabadaj, M.; González-Calabuig, A.; Wróblewski, W.; Legin, A. Independent comparison study of six different electronic tongues applied for pharmaceutical analysis. J. Pharm. Biomed. Anal. 2015, 114, 321-329. [CrossRef]

207. Tirzīte, M.; Bukovskis, M.; Strazda, G.; Jurka, N.; Taivans, I. Detection of lung cancer with electronic nose and logistic regression analysis. J. Breath Res. 2018, 13, 016006. [CrossRef]

208. Herman-Saffar, O.; Boger, Z.; Libson, S.; Lieberman, D.; Gonen, R.; Zeiri, Y. Early non-invasive detection of breast cancer using exhaled breath and urine analysis. Comput. Biol. Med. 2018, 96, 227-232. [CrossRef]

209. De León-Martíne, L.D.; Rodríguez-Aguilar, M.; Gorocica-Rosete, P.; Domínguez-Reyes, C.A.; Martínez-Bustos, V.; Tenorio-Torres, J.A.; Ornelas-Rebolledo, O.; Cruz-Ramos, J.A.; Balderas-Segura, B.; Flores-Ramírez, R. Identification of profiles of volatile organic compounds in exhaled breath by means of an electronic nose as a proposal for a screening method for breast cancer: A case-control study. J. Breath Res. 2020, 14, 046009. [CrossRef]

210. Farraia, M.; Rufo, J.C.; Paciência, I.; Mendes, F.C.; Rodolfo, A.; Rama, T.A.; Rocha, S.; Delgado, L.; Brinkman, P.; Moreira, A. Human volatilome analysis using eNose to assess uncontrolled asthma in a clinical setting. Allergy 2020, 75, 1630-1639. [CrossRef]

211. Tenero, L.; Sandri, M.; Piazza, M.; Paiola, G.; Zaffanello, M.; Piacentini, G.L. Electronic nose in discrimination of children with uncontrolled asthma. J. Breath Res. 2020, 14, 046003. [CrossRef]

212. Dragonieri, S.; Quaranta, V.N.; Carratu, P.; Ranieri, T.; Marra, L.; D’Alba, G.; Resta, O. An electronic nose may sniff out amyotrophic lateral sclerosis. Respir. Physiol. Neurobiol. 2016, 232, 22-25. [CrossRef]

213. Zheng, X.-Z.; Lan, Y.-B.; Zhu, J.-M.; Westbrook, J.; Hoffmann, W.C.; Lacey, R.E. Rapid identification of rice samples using an electronic nose. J. Bionic Eng. 2009, 6, 290-297. [CrossRef]

214. Li, C.; Krewer, G.W.; Ji, P.; Scherm, H.; Kays, S.J. Gas sensor array for blueberry fruit disease detection and classification. Postharvest Biol. Technol. 2010, 55, 144-149. [CrossRef]

215. Autelitano, F.; Giuliani, F. Analytical assessment of asphalt odor patterns in hot mix asphalt production. J. Clean. Prod. 2018, 172, 1212-1223. [CrossRef]

216. Autelitano, F.; Giuliani, F. Influence of chemical additives and wax modifiers on odor emissions of road asphalt. Constr. Build. Mater. 2018, 183, 485-492. [CrossRef] 
217. Hosfield, B.D.; Pecoraro, A.R.; Baxter, N.T.; Hawkins, T.B.; Markel, T.A. The assessment of fecal volatile organic compounds in healthy infants: Electronic nose device predicts patient demographics and microbial enterotype. J. Surg. Res. 2020, 254, 340-347. [CrossRef] [PubMed]

218. Baietto, M.; Wilson, A.D.; Bassi, D.; Ferrini, F. Evaluation of three electronic noses for detecting incipient wood decay. Sensors 2010, 10, 1062-1092. [CrossRef] [PubMed]

219. Wilson, A.D.; Oberle, C.S.; Oberle, D.F. Detection of off-flavor in catfish using a conducting polymer electronic-nose technology. Sensors 2013, 13, 15968-15984. [CrossRef]

220. Voss, H.G.J.; Júnior, J.J.A.M.; Farinelli, M.E.; Stevan, J.S.L. A prototype to detect the alcohol content of beers based on an electronic nose. Sensors 2019, 19, 2646. [CrossRef] 